\title{
Study of recycled concrete aggregate quality and its relationship with recycled concrete compressive strength using database analysis
}

\author{
I. González-Taboada, B. González-Fonteboa $\bowtie$, F. Martínez-Abella, D. Carro-López \\ Department of Construction Technology, E.T.S.I. Caminos, Canales, Puertos. \\ University of A Coruña. Campus Elviña (A Coruña, Spain) \\ \bfonteboa@udc.es
}

Received 31 July 2015

Accepted 18 December 2015

Available on line 28 June 2016

\begin{abstract}
This work studies the physical and mechanical properties of recycled concrete aggregate (recycled aggregate from concrete waste) and their influence in structural recycled concrete compressive strength. For said purpose, a database has been developed with the experimental results of 152 works selected from over 250 international references.

The processed database results indicate that the most sensitive properties of recycled aggregate quality are density and absorption. Moreover, the study analyses how the recycled aggregate (both percentage and quality) and the mixing procedure (pre-soaking or adding extra water) influence the recycled concrete strength of different categories (high or low water to cement ratios). When recycled aggregate absorption is low (under 5\%), pre-soaking or adding extra water to avoid loss in workability will negatively affect concrete strength (due to the bleeding effect), whereas with high water absorption this does not occur and both of the aforementioned correcting methods can be accurately employed.
\end{abstract}

KEYWORDS: Concrete; Recycled aggregate; Compressive strength; Mechanical properties; Physical properties

Citation/Citar como: González-Taboada, I.; González-Fonteboa, B.; Martínez-Abella, F.; Carro-López, D. (2016) Study of recycled concrete aggregate quality and its relationship with recycled concrete compressive strength using database analysis. Mater. Construcc. 66 [323], e089. http://dx.doi.org/10.3989/mc.2016.06415.

RESUMEN: Estudio de la calidad del árido reciclado y su relación con la resistencia a compresión del hormigón reciclado utilizando una base de datos. El estudio analiza las propiedades físico-mecánicas de los áridos reciclados de hormigón (procedentes de residuos de hormigón) y su influencia en la resistencia a compresión del hormigón reciclado estructural. Para ello se ha desarrollado una base de datos con resultados de 152 trabajos seleccionados a partir de más de 250 referencias internacionales.

Los resultados del tratamiento de la base indican que densidad y absorción son las propiedades más sensibles a la calidad del árido reciclado. Además, este estudio analiza cómo el árido reciclado (porcentaje y calidad) y el procedimiento de mezcla (presaturación o adición de agua extra) influyen en la resistencia del hormigón reciclado de diferentes categorías (alta o baja relación agua-cemento). Cuando la absorción es baja (inferior al 5\%) presaturar o añadir agua para evitar pérdidas de trabajabilidad afectan negativamente a la resistencia (debido al bleeding), mientras que cuando es alta esto no sucede y ambos métodos son adecuados.

PALABRAS CLAVE: Hormigón; Árido reciclado; Resistencia a la compresión; Propiedades mecánicas; Propiedades físicas

Copyright: (C) 2016 CSIC. This is an open-access article distributed under the terms of the Creative Commons Attribution License (CC BY) Spain 3.0. 


\section{INTRODUCTION AND SCOPE OF THIS PAPER}

In recent decades, a social movement of environmental awareness has developed where the protection of natural resources and sustainable development play an essential role in the modern requirements of construction works $(1,2)$. The use of recycled concrete aggregate has increased in recent years backed by extensive scientific research. A significant number of research papers have been published which has reduced the uncertainty related to its performance. Therefore, the creation of a database (3-154) including these published results (Figure 1) is very useful for making general conclusions.

The objective of this database analysis is to achieve a full understanding of recycled concrete aggregates and propose a design methodology for structural recycled concrete, based on the physicalmechanical properties of recycled concrete coarse aggregates studied using the database.

The quality of recycled aggregate concrete depends on the properties of the recycled aggregates. This paper deals with the study of aggregates recycled from concrete waste, which are the most suitable aggregates for creating structural recycled concrete. Apart from the natural aggregate, the other main component of this recycled aggregate is the adhered cement mortar. This material is the cause of the main differences between natural aggregates and recycled concrete aggregates (6).

Undoubtedly, there is significant variation in the quality of this kind of aggregate. Firstly, it is related to the original concretes and their differences. Low grade original concrete leads to low grade adhered mortar and consequently, low grade recycled aggregates. Secondly, the recycling process is also important because it influences the amount (quantity) of attached mortar, which decreases as the stages in the crushing process increase (105). Finally, it should be noted that there is a significant difference between the properties of recycled coarse aggregates and recycled fine aggregates which always contains a much higher proportion of adhered mortar.

Therefore, the original concrete, the recycling process and the size fraction are the three most important issues that should be controlled when producing recycled concrete aggregates.

From a practical point of view, it would be very interesting to establish patterns or relationships between the different physical-mechanical properties of recycled aggregate and also, between these properties and recycled concrete compressive strength.

To achieve this objective, a database has been developed (3-154). This database has been built using 152 works that deal with recycled concrete aggregates, after studying over 250 international works related to recycled aggregates. The inclusion criterion was the fact that the characterization of the aggregates used should be shown, both for natural and recycled aggregates, and this characterization should include at least the following values: size fraction, water absorption, saturated surface dry density and, whenever possible, composition, Los Angeles coefficient, shape coefficient, fineness modulus and other types of density.

Recently, a wide range of reviews have been published by authors proposing a performance-based classification for the use of recycled aggregates in

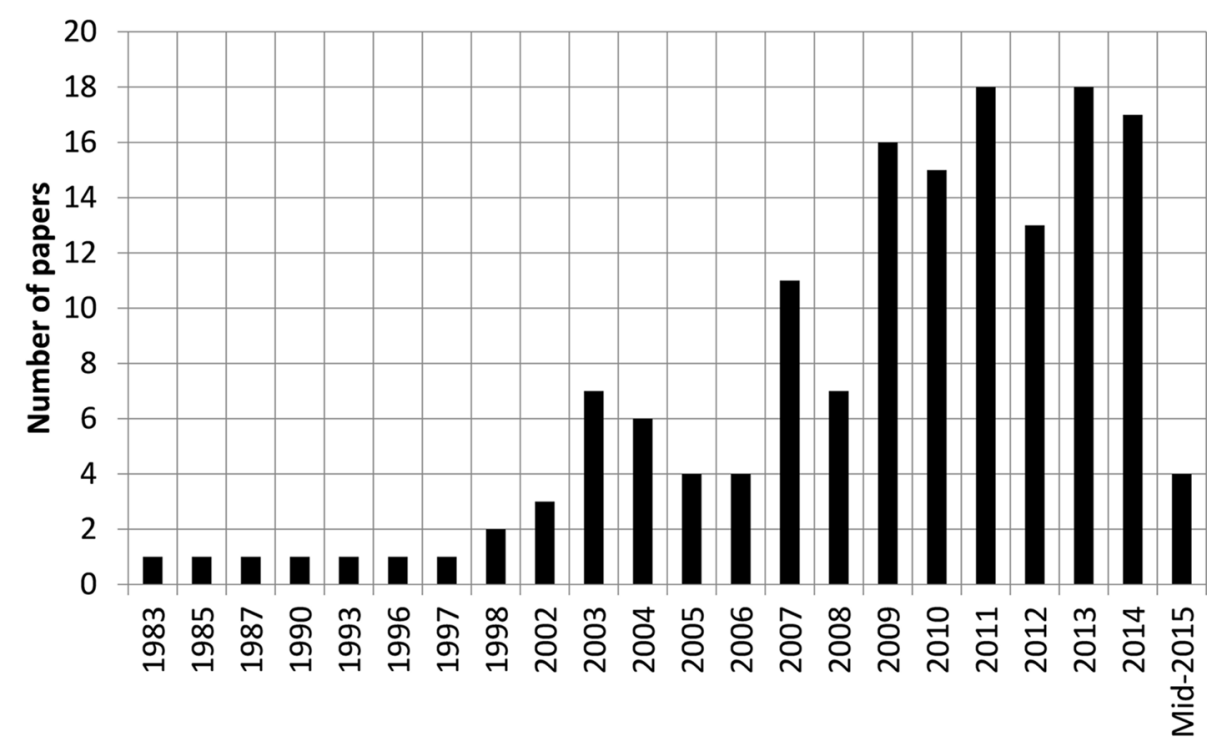

Year of publication

FIGURE 1. Year of publication vs. Number of papers (recycled concrete aggregate database). 
concrete construction (155) and a model to predict the strength loss based on the quality and content of recycled aggregates (156). Others have modelled the compressive strength of recycled concrete using artificial neural networks (157), while others have presented a range for recycled concrete components using sensitivity analysis with neural networks (158), although no expressions have been presented.

However, the objective of this work is not to propose a prediction methodology for recycled concrete compressive strength. There are many variables that influence recycled concrete compressive strength (grading curves, maximum size fraction, natural aggregate source, cement class, possible admixtures, etc.) which have not been taken into account. In fact, it is really difficult to take all these variables into account. Furthermore, compressive strength is usually experimentally measured and adjusted after different mixing tests. Consequently, the objective of this work is to analyse how the recycled concrete aggregate (both percentage and quality) and the mixing procedure (pre-soaking or adding extra water) influence the recycled concrete strength of different categories (high or low water to cement ratios), in order to establish suitable production or manufacturing recommendations to promote further use of recycled concrete.

\section{PROPERTIES OF RECYCLED CONCRETE AGGREGATES}

\subsection{Composition}

Recycled aggregates are defined as aggregates obtained from the treatment of inorganic material which has been previously used in construction (159). The raw material is the waste material generated during the construction and demolition processes. Regarding the particular case of recycled concrete aggregate, this is obtained from the recycling process of concrete waste material.

Therefore, the recycled concrete aggregates are mainly made of natural aggregate and adhered cement mortar. However, it may incorporate impurities and contaminants, which have a negative influence on the properties of the final recycled concrete (149). These impurities can be very diverse, such as plastic, wood, gypsum, bricks, ceramics, organic material, asphalt, aluminium, etc.

The composition of the recycled aggregates depends on the type of original waste, the recycling plant production process and the size fraction obtained through the crushing process, and can differ depending on these three factors.

Aggregate from concrete demolition and debris generally presents a low quantity of impurities $(160,161)$, however, the results for the compositions of recycled concrete aggregates obtained from literature are not significant enough to encounter any kind of relationship. Figure 2 shows an example of the composition of these aggregates measured according to EN 933-11 "Test for the classification of recycled aggregates according to their composition". It can be seen that materials from concrete (mortar, aggregates and aggregates with mortar) make up over $90 \%$ of the total.

Most standards and recommendations classify recycled aggregates in terms of their composition (162). In the case of recycled aggregates suitable for recycled concrete, a minimum material from concrete waste of $90 \%$ is usually imposed (Brazilian, German, Rilem and Belgian standards) and also a maximum of $10 \%$ masonry material is established. In the United Kingdom, the Netherlands, Norway and Denmark, more than $95 \%$ of waste concrete is required and the masonry limit is fixed at 5\% (162-168). The Spanish standard (169) establishes a maximum of masonry content at $5 \%$, of lightweight material at $1 \%$, of asphalt at $1 \%$ and finally, the sum of other materials like glass, plastic, metals, etc. must be under $1 \%$.

In general, with a suitable crushing process, the recycled coarse aggregates from waste concrete can deal with these limits.

\subsection{Adhered mortar}

The main differences between recycled concrete aggregate and natural aggregate are due to the presence of adhered cement mortar (110). This new material makes the aggregate density lower and the water absorption and Los Angeles coefficient higher, which means lower fragmentation resistance. Consequently, the quality and quantity of adhered mortar is one of the key factors controlling the quality of recycled concrete aggregates and, indeed, the performance of recycled concrete (170).

It is well known that the quality and quantity of adhered mortar is influenced by the quality of the original or parent concrete, production treatment designed in production plants and size fraction of the aggregates.

The influence of the original concrete is not clear. Some researchers explain that, during the

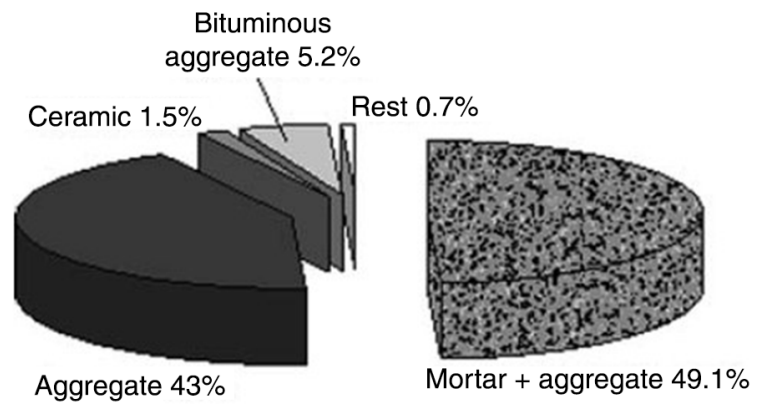

FIGURE 2. Recycled concrete aggregates composition (47). 
crushing process of low strength original concrete, most of the mortar gets separated from the original aggregate because the bond between mortar and aggregate is weak. As this mortar gets crushed into fine particles, it is then removed during the sieving process. Therefore, the recycled coarse aggregate obtained from this low strength original concrete presents a lower quantity of mortar. However, others explain that the quality of attached mortar in recycled aggregates is lower when obtained from low strength original concretes than when obtained from high strength ones, as the water to cement ratio of the low strength concretes is high and hence, the mortar obtained with them is more porous.

With regards to production, a number of works can be seen in the literature which proposes the improvement of recycled aggregate quality by reducing the adhered mortar using special production treatments. There are different treatment options, with some authors proposing one or a combination of mechanical grinding processes (also increasing the number of crushing processes (171)), others using thermal treatments (microwave or conventional heating) (7) and, finally, others using chemical treatments (pre-soaking or cycle soaking the recycled aggregates in different acidic solvents, namely hydrochloric acid, sulphuric acid, and phosphoric acid) (172). In this regard, an investigation has been carried out that deals with the influence of different polymer treatments on recycled aggregates that has been already used in the protection of structures (grout, render, etc.) (173). However, so far none of these treatments have been developed in the industry.

Finally, it is also clear that the crushing process reduces the size of waste material and, as the weakest phase of this material is the adhered mortar, it will be more affected by the crushing process than the original aggregates. In this regard, the fine fractions will be mainly composed of adhered mortar. Therefore, the greater the quantity of adhered mortar the finer the size fraction of aggregate.

The presence of adhered mortar implies that, while conventional concrete is a three-phase composite material (on a microscopic scale) with a mortar matrix, aggregates and one interfacial transition zone between these two zones (paste-aggregate interface), recycled concrete has two interfaces, the interface between adhered mortar and the original aggregate and the new interfacial transition zone between the new mortar and the recycled aggregate. The adhered mortar makes bonding between the recycled aggregate and the new mortar (new interface, Figure 3) weaker, which leads to worse recycled concrete performance, affecting properties related to deformation (modulus of elasticity, drying shrinkage and creep), durability (water absorption and permeability) and, of course, mechanical behaviour (strength) $(61,64)$. Moreover, the adhered mortar also controls the concrete's workability. As the adhered mortar increases, the water absorption also increases and the fresh mixture's workability decreases.

Regarding the mortar content, the literature shows some randomness. Hansen and Narud (64) reported that the mortar content varied from 30 , 39 and 60 percent for $16-30 \mathrm{~mm}, 8-16 \mathrm{~mm}$ and $4-8$ $\mathrm{mm}$ fractions respectively and assessed that original concrete quality hardly influences this quantity. However, according to $\mathrm{Li}$ (175), the percentage of old mortar (around 20-30\%), mainly depends on the properties of the original concrete and the production process. Ravindrarajah and Tam (125) stated that, in general, recycled coarse aggregates contain an average of about $50 \%$ adhered mortar. On the other hand, Sánchez and Alaejos (171) found ranges of $23-44 \%$ for $8-16 \mathrm{~mm}$ fraction and of $33-55 \%$ for $4-8 \mathrm{~mm}$ fraction. This heterogeneity of results is probably due to the difficulty in measuring the adhered mortar quantity, the different original concretes used and, of course, the different treatments designed to manage construction and demolition waste.

\subsection{Shape and particle size distribution}

Recycled aggregate grading is directly linked to the crushing process applied to the original concrete waste (38). Furthermore, this process is restricted by
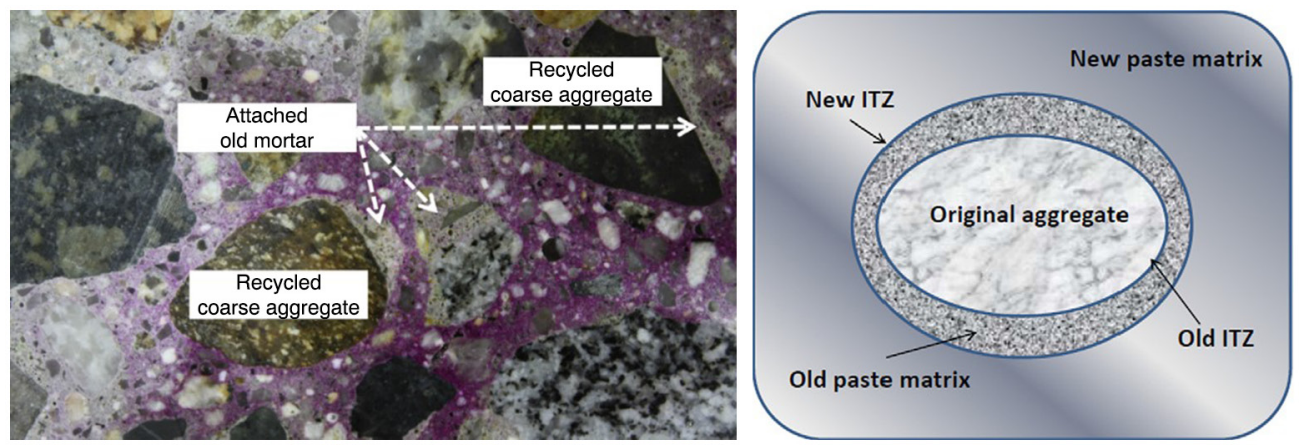

FIGURE 3. Recycled aggregate interface (91) (174).

NoTE: RCA (recycled coarse aggregate); RFA (recycled fine aggregate). 
the grading curves set out by countries in their regulations (159).

If a grain size distribution analysis of natural and recycled aggregates is carried out, a different pattern of behaviour is observed for coarse and fine aggregates. The grain size distribution of recycled coarse aggregate does not differ appreciably from natural coarse aggregates. Hence, the recycled aggregate fineness modulus undergoes small variations for the same maximum aggregate size, depending mainly on the crushing process used and the original concrete quality (160).

However, the recycled fine aggregate grading generally shows thicker size fractions than conventional fine aggregate. Debieb et al. (40) even points out that recycled sand consists mainly of gravel and a small quantity of medium-sized sand.

Seventy-one different datasets were considered in the database. The fineness modulus obtained from different authors vary in the range of 5.70 to 7.36 for maximum aggregate sizes between 10 and $25 \mathrm{~mm}$, as shown on Figure 4, with an average value of 6.55 .

Due to the presence of attached mortar, the surface texture of the recycled coarse aggregates is found to be more porous and rough (10, 38 and 150) than that of the natural aggregate.

Furthermore, it should be taken into account that recycled aggregate generates fines during its manipulation due to the production of small mortar particles. The presence of these fine particles in the recycled coarse aggregate may decrease the bond between the recycled aggregate and the new cement paste and increase the mixing water necessary to achieve fixed workability when the concrete is made (130). The Spanish standard limits the fines content to $1 \%$ (169). The Belgian, British and
German codes, the Rilem recommendation and the Hong Kong specifications establish a higher limit, which is between $2 \%$ and $5 \%(159,163,164,167$, 168).

In general, the particle shape of recycled aggregates is determined by the crushing equipment. Impact mills used in recycling plants produce cube-shaped aggregates because concrete tends to break into small blocks without generating slabs (176). In this way, the shape index of recycled and natural coarse aggregate is similar. According to the studies checked $(12,38,39,48$, $53,57,61,97,142,177,178)$, this index presents a range of values from 0.14 to 0.47 when recycled aggregate is analysed and from 0.19 to 0.58 for natural aggregate. In general, the limit established in the Spanish specification (169) can be fulfilled without any problem.

\subsection{Water absorption}

The database has verified the usual statement that the water absorption of recycled aggregates is much higher than that of natural aggregates (3-154). The main reason for this difference is the presence of cement mortar that remains attached to the recycled aggregate particles. This cement mortar has higher porosity than the aggregates and therefore, recycled aggregates absorb more water than the conventional kind.

The natural aggregate water absorption usually ranges between $0 \%$ and $4 \%$. However, drawing an analysis from the database (two hundred and ninetynine datasets), the water absorption values obtained for recycled aggregates ranges from $1.65 \%$ to $13.1 \%$, with an average value of $5.32 \%$.

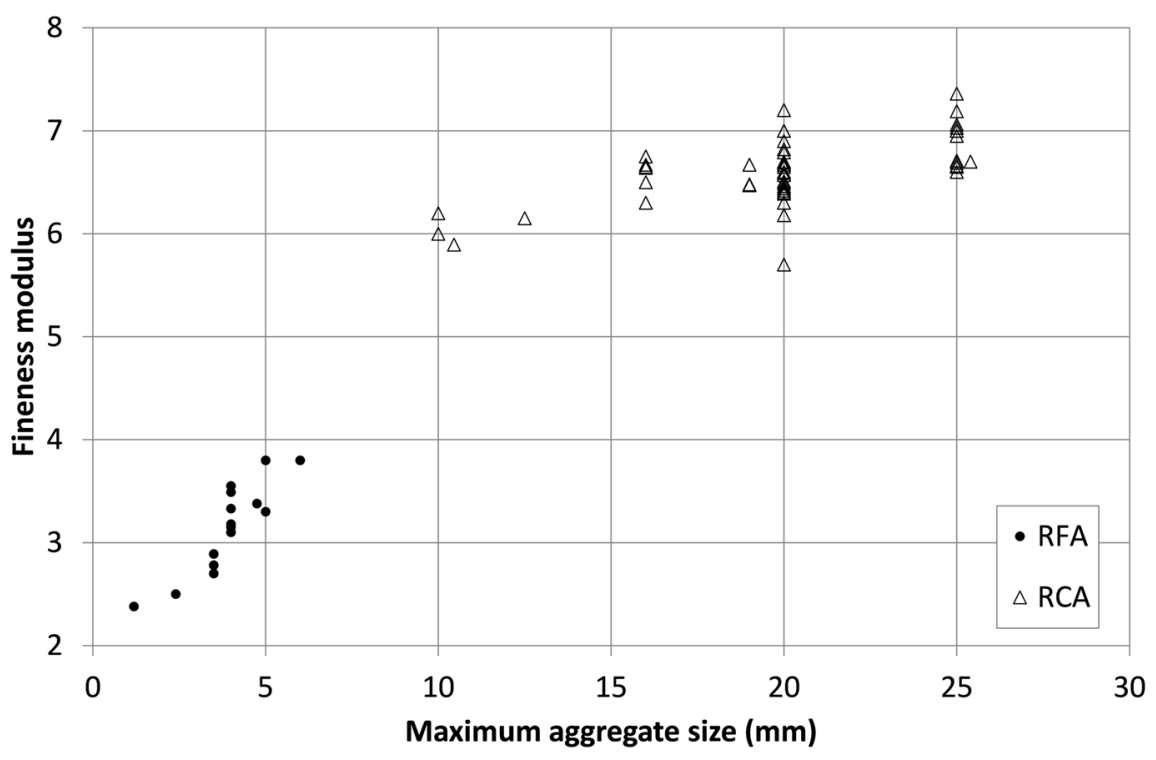

FIGURE 4. Recycled concrete aggregate fineness modulus vs. Maximum aggregate size. 
Furthermore, because of the fact that the percentage of adhered mortar is higher in the sand fraction than in the coarse fraction (151), water absorption increases as the size fraction decreases. As already noted, since the weakest phase of waste material is the adhered mortar, it will be more affected by the crushing process than the original aggregates. In this regard, the fine fractions will mainly consist of adhered mortar.

This trend is shown on Figure 5, highlighting the important influence of the size of recycled aggregate on its water absorption capacity. In this regard, the water absorption of recycled coarse aggregate varies from 1.12 to $8.82 \%$, with an average value of $5.06 \%$, whereas the water absorption of recycled fine aggregate varies from $6.84 \%$ to $13.1 \%$, with an average value of $9.89 \%$. However, for the same maximum aggregate size some scatter can be observed, due to the fact that this property is also influenced by the original waste and the crushing processes.

With regards to original waste, a high quantity of impurities (especially ceramic material) will increase water absorption (179). However, once again, the influence of the original concrete is not clear, with some researchers indicating that high grade original concrete can make water absorption lower $(64,105)$ while others $(26,108)$ state that the water absorption of recycled aggregates increases as the original concrete strength increases. This depends on whether the main effect is the quantity of adhered mortar (low strength original concrete presents lower quantity of mortar) or its quality (low strength concrete presents more porous adhered mortar).
Finally, concerning the crushing process, it is clear that a high number of crushing processes leads to lower water absorption values $(48,180)$, due to the fact that these crushing processes reduce the size of the cement adhered mortar which is finally eliminated during the sieving process.

Most international standards set out limits for the water absorption of recycled aggregate. The Rilem recommendations establish a maximum value of $10 \%$ for aggregate type II, an aggregate mostly from concrete rubble (ceramic content under 10\%) (167). This value is also accepted in the recommendations of Hong Kong and Norway (162 and 168). In the German standards, maximum water absorption after 10 minutes is established at 10\% (159). The Belgian specifications are very similar to the Rilem, establishing maximum water absorption at $9 \%$ for the recycled aggregate known as GBSB-II, which is the equivalent of the aforementioned aggregate type II. The Australian guide only admits a water absorption capacity of $6 \%$. In Japan, different requirements are demanded depending on the application of the aggregates (181-183); when the highest grade of recycled aggregate (type $\mathrm{H}$ ) is analysed, the water absorption capacity must be under $3 \%$. The Brazilian and Portuguese specifications allow a maximum water absorption value of $7 \%(165,184)$. The Spanish standard (169) establishes the limit at 7\%, when only $20 \%$ of recycled coarse aggregate is going to be used and the natural coarse aggregate shows a water absorption capacity lower than $4.5 \%$. When more than $20 \%$ of recycled coarse aggregate is going to be used, the mix of natural and recycled coarse aggregate should maintain an absorption capacity no greater than $5 \%$.

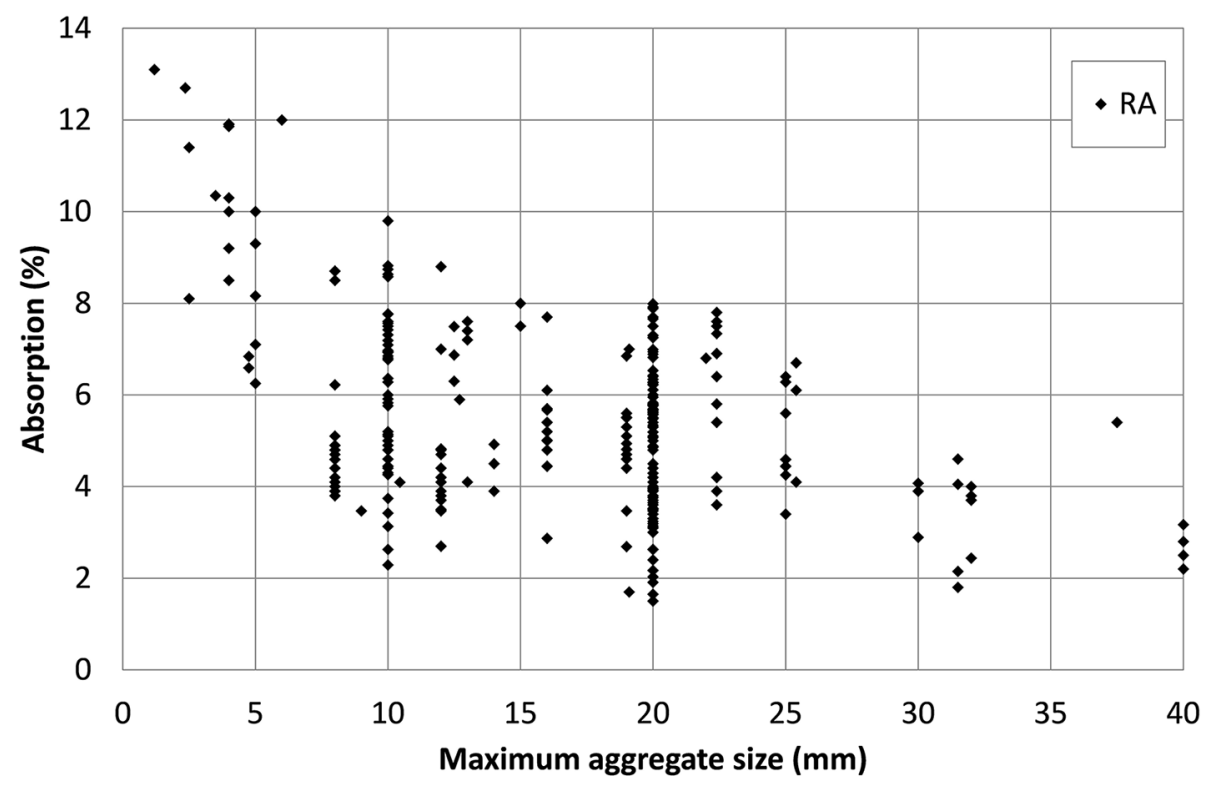

FIGURE 5. Water absorption vs. Maximum aggregate size. NoTE: RA (recycled aggregate). 
Actually, water absorption develops over time, with EN 1097-6 establishing that it should be measured after soaking aggregates in water for at least 24 hours. However, many authors agree with the fact that in the first 10 minutes the recycled coarse aggregates can achieve $80-90 \%$ of their water absorption capacity $(4,7,185)$. For this reason water absorption at 10 minutes is a very useful value when designing, as it can be used to calculate the extra water needed to maintain workability or define the pre-soaking aggregate time.

Belin et al. (15) concluded that water absorption at $24 \mathrm{~h}$ can be seen as the simple sum of the capillary absorption of both residual cement paste and initial natural aggregates. They propose a tentative framework for the classification of recycled concrete aggregate based on the water absorption rate and the water absorption capacity at $24 \mathrm{~h}$.

On the other hand, Djerbi (43) has obtained a long saturation time for recycled aggregates $(>24 \mathrm{~h})$. He concludes that the standard method of $24 \mathrm{~h}$ stipulated in European standards is not suitable for water absorption measurements of recycled aggregates. The water absorption coefficient of recycled aggregates for $24 \mathrm{~h}$ of soaking produces about $60 \%$ and $70 \%$ of the total water absorption obtained after $85 \mathrm{~h}$ and $110 \mathrm{~h}$ of soaking for the $12.5-20 \mathrm{~mm}$ fraction and $5-12.5 \mathrm{~mm}$ fraction respectively. He presents a hydrostatic weighing approach and concludes that this new approach allows engineers to determine the test time and that it improves the precision of water absorption measurements for aggregates.

\subsection{Saturated surface dry density}

Recycled concrete aggregate density is proved to be lower than that of natural aggregate. Surface dry density or SSD density is often used in the field of concrete.

As a general rule, it is verified that the higher the content of attached mortar and impurities, the lower the recycled coarse aggregate density (176). In this regard, again, this property is influenced by the original waste, processing level and size fraction.

Adhered mortar is a porous material with a density of around $1.0-1.6 \mathrm{~kg} / \mathrm{m}^{3}$, which is lower than that of natural aggregate particles (186). Furthermore, the adhered mortar porosity depends on the water/cement ratio of the parent concrete. Higher strength original concrete provides denser and higher quality adhered mortar, than that obtained from lower strength concrete. However, again, the quantity of cement mortar will be higher in recycled coarse aggregate obtained from high strength concrete. Finally, the type and density of virgin aggregate also plays an important role. Some researchers indicate that it affects recycled aggregate properties more than the water to cement ratio of the original concrete (187).

Once again, as the weakest phase of the virgin waste material is the adhered mortar, this will be affected to a greater extent by the crushing process than the original aggregate. In this regard, the adhered mortar will mainly be present in the fine fractions.

Regarding the multiple crushing of source concretes, this reduces the number of particles with cracks, microdefects or voids in the coarse fractions of aggregate. Furthermore, again, the crushing process reduces the size of the adhered cement mortar (weak and easily crushed) which is finally eliminated during the sieving process (powder) or used as recycled fine aggregate. Consequently, the recycled concrete coarse aggregate obtained at each stage of the recycling process improves in density value. Some countries have tried to develop a closed-loop recycling system to improve the coarse aggregate properties and, at the same time, handle the large amount of crushed concrete fines and powder generated during the recycling process for producing recycled cement.

Figure 6 shows the relationship between maximum aggregate size and density values. As the aggregate size increases, the density value also increases (due to the fact that the adhered mortar content has decreased with the aggregate size). For the same size fraction, some scatter in the data from the literature (two hundred and seventy-four datasets) (Figure 6) is observed. This is due to the different qualities of the original waste (this property is influenced by original aggregate density) and, also the number of crushing processes undergone by the concrete debris.

The SSD density of the recycled concrete aggregate ranges from 2150 to $2680 \mathrm{~kg} / \mathrm{m}^{3}$. The density values of recycled coarse aggregate vary from 2280 to $2680 \mathrm{~kg} / \mathrm{m}^{3}$, higher than that of fine aggregate. This recycled coarse aggregate presents an average value of $2397 \mathrm{~kg} / \mathrm{m}^{3}$ for a particle size under $16 \mathrm{~mm}$ and $2458 \mathrm{~kg} / \mathrm{m}^{3}$ when higher fractions are analysed. The average value of the SSD density of the recycled coarse aggregate is $2437 \mathrm{~kg} / \mathrm{m}^{3}$. On the other hand, fine aggregate (maximum size fraction under $4 \mathrm{~mm}$ ) shows SSD density values, generally, under $2350 \mathrm{~kg} /$ $\mathrm{m}^{3}$ and an average value of $2312 \mathrm{~kg} / \mathrm{m}^{3}$.

The standards for Germany, Hong-Kong, Netherlands, Portugal, Norway and Denmark and the RILEM recommendation establish a minimum density value for recycled concrete aggregate between 2000 and $2200 \mathrm{~kg} / \mathrm{m}^{3}$. The Rilem recommendation considers that the percentage of material with an SSD density value under $2200 \mathrm{~kg} / \mathrm{m}^{3}$ must be under $10 \%(159,162,164,167,168)$.

All authors point out that as water absorption increases, SSD density decreases. This trend can be observed on Figure 7 (two hundred and forty-seven datasets) which represents the relationship between SSD density and the water absorption capacity. The 


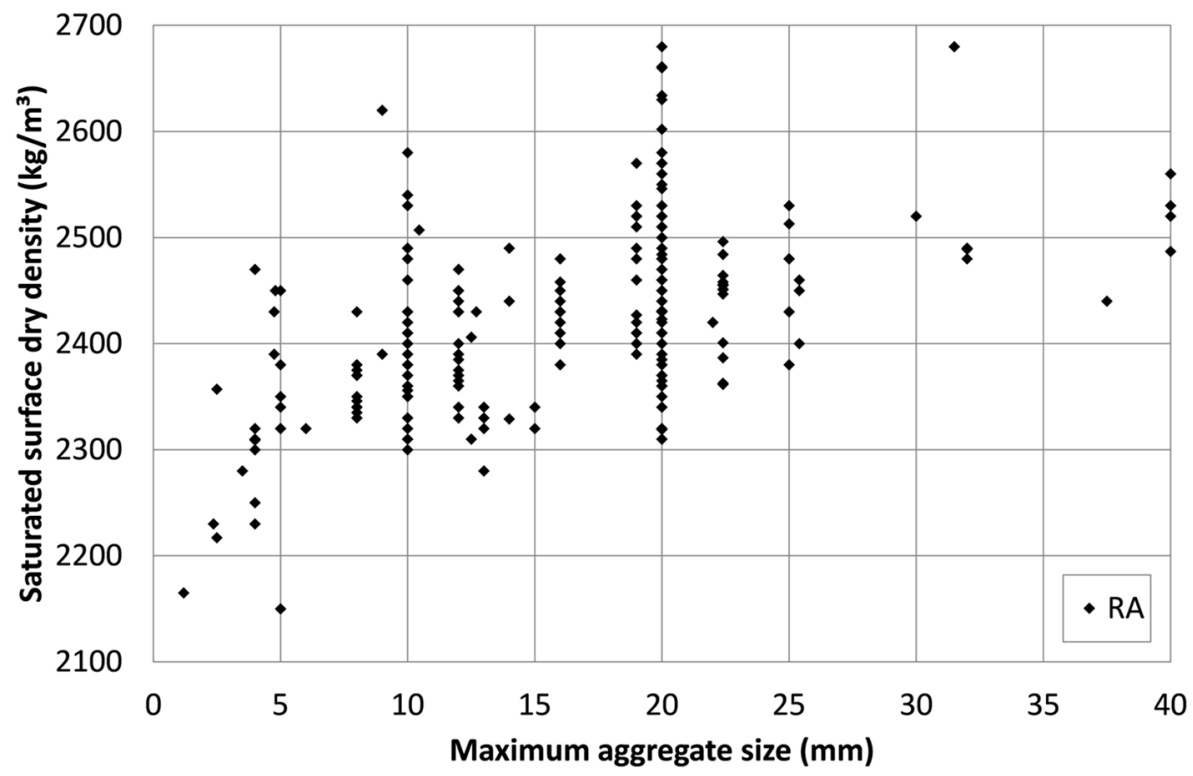

Figure 6. Saturated surface dry density vs. Maximum aggregate size. NOTE: RA (recycled aggregate).

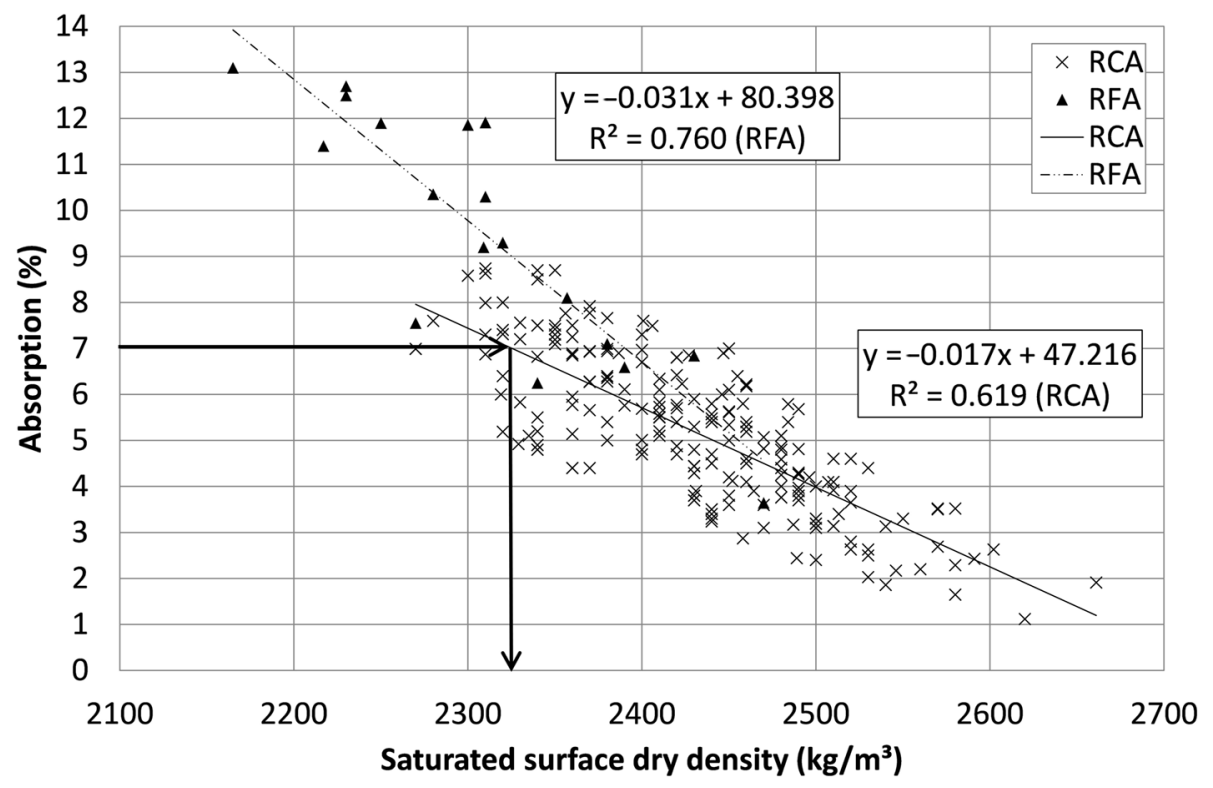

FIGURE 7. Water absorption vs. Saturated surface dry density.

NOTE: RCA (recycled coarse aggregate); RFA (recycled fine aggregate).

expression which links both values changes as a function of aggregate size.

Figure 7 shows that recycled coarse aggregate with water absorption values under $7 \%$ corresponds with density values over $2300 \mathrm{~kg} / \mathrm{m}^{3}$.

\subsection{Abrasion resistance}

Researchers use different methods to measure the hardness and abrasion resistance of aggregates (44, 79 and 87). However, the Los Angeles abrasion test is one of the most common methods and hence, the Los Angeles coefficient is the value that has been used to study recycled aggregate behaviour.

In general, recycled concrete aggregate shows higher Los Angeles values than natural aggregate because weight loss is due to two causes: loss of adhered mortar and loss of original aggregate (180).

Several researchers have observed that the resistance to crushing, impact and abrasion of recycled aggregates is relatively lower than that of virgin aggregates (188), due to the separation and crushing 
of the porous mortar coating from the recycled aggregate during testing.

Regarding parent concrete, again it depends on whether the main effect is the quantity of adhered mortar (low strength original concrete presents lower quantity of mortar) or its quality (low strength concrete presents more porous adhered mortar). Furthermore, this property is not only influenced by the water to cement ratio. For a given strength of parent concrete, the resistance to mechanical action decreases as the maximum aggregate size decreases. This can be attributed to the relatively larger surface area of smaller sized aggregates facilitating higher mortar coating, compared to larger sized aggregates. Finally, again, recycled aggregate obtained from concrete with a low water/cement ratio may exhibit a higher abrasion value than others from a concrete with a high water/cement ratio. This is due to the fact that the water/cement ratio of the original concrete is relatively less important than the abrasion loss value of the natural aggregate it contains (187).

Of course, again, a high number of crushing processes leads to better behaviour against impact and abrasion, due to the fact that these crushing processes reduce the size of the cement adhered mortar which is finally eliminated during the sieving process.

Figure 8 shows the results of the Los Angeles coefficient as a function of maximum aggregate size. Ninety different datasets were considered in the database. It can be seen that this coefficient is influenced by aggregate size. As the aggregate size decreases, the Los Angeles coefficient increases (meaning a decrease in abrasion resistance). This is due to the fact that the fine fractions have a higher percentage of attached mortar than the coarse kind (19). However, in this case, high scatter can be observed. This is due to the different qualities of original waste (also this property is influenced by the original aggregate) and the number of crushing processes used in the plant.

The values obtained from the literature range generally between $25 \%$ and $40 \%$, with an average value of $32 \%$.

In general the standards do not establish additional requirements for the Los Angeles coefficient. Some of them propose other types of tests to evaluate aggregate abrasion resistance $(159,168)$.

Figure 9 (with fifty-eight datasets) shows the relationship between the Los Angeles coefficient and the water absorption capacity of recycled concrete aggregate. Figure 9 shows that recycled coarse aggregate with water absorption values under 7\% results in a Los Angeles coefficient under $42 \%$.

Figure 10 (with fifty-five datasets) shows the relationship between the Los Angeles coefficient and density of recycled concrete aggregate. In this case, as the density values decrease, the Los Angeles coefficient increases. Figure 10 shows that recycled coarse aggregates with Los Angeles coefficient values under $42 \%$ correspond with density values over $2410 \mathrm{~kg} / \mathrm{m}^{3}$.

\section{INFLUENCE OF CONCRETE RECYCLED AGGREGATE PROPERTIES ON CONCRETE COMPRESSIVE STRENGTH}

Figure 11 shows the relationship between the cube compressive strength of recycled concrete and the water/cement ratio $(\mathrm{w} / \mathrm{c})$ as a function of the

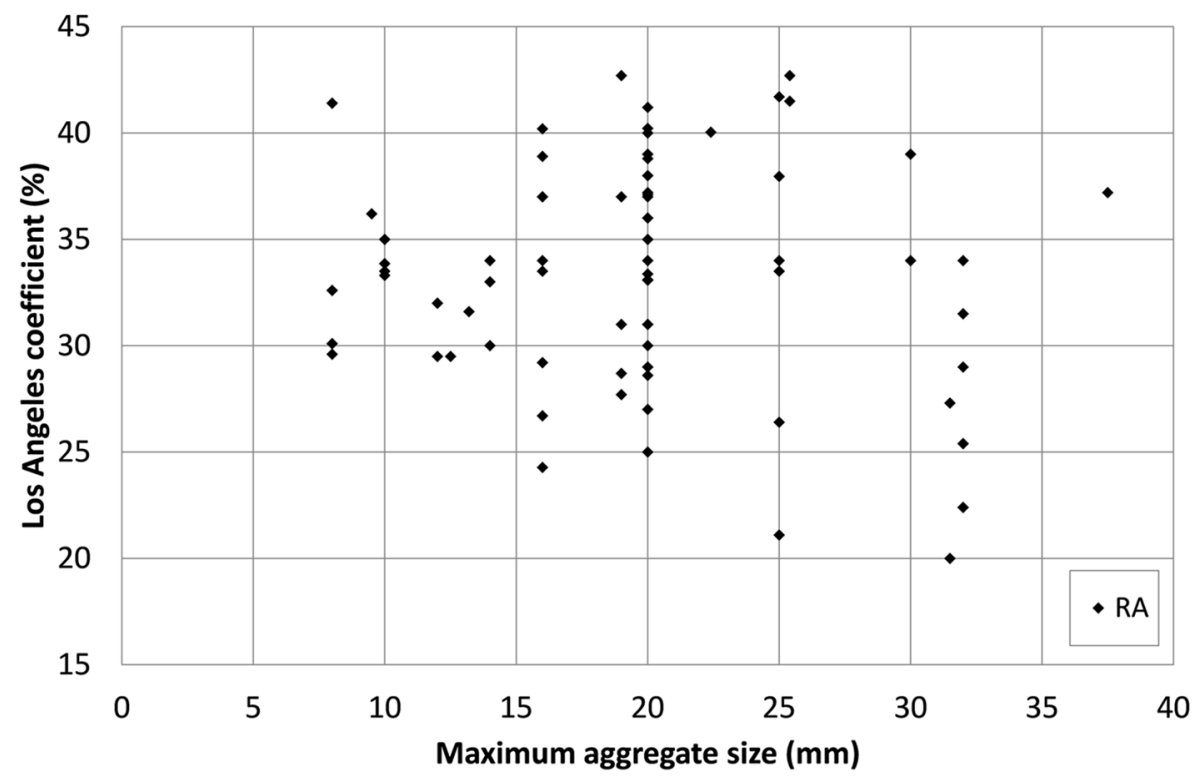

Figure 8. Los Angeles coefficient vs. Maximum aggregate size. NOTE: RA (recycled aggregate). 


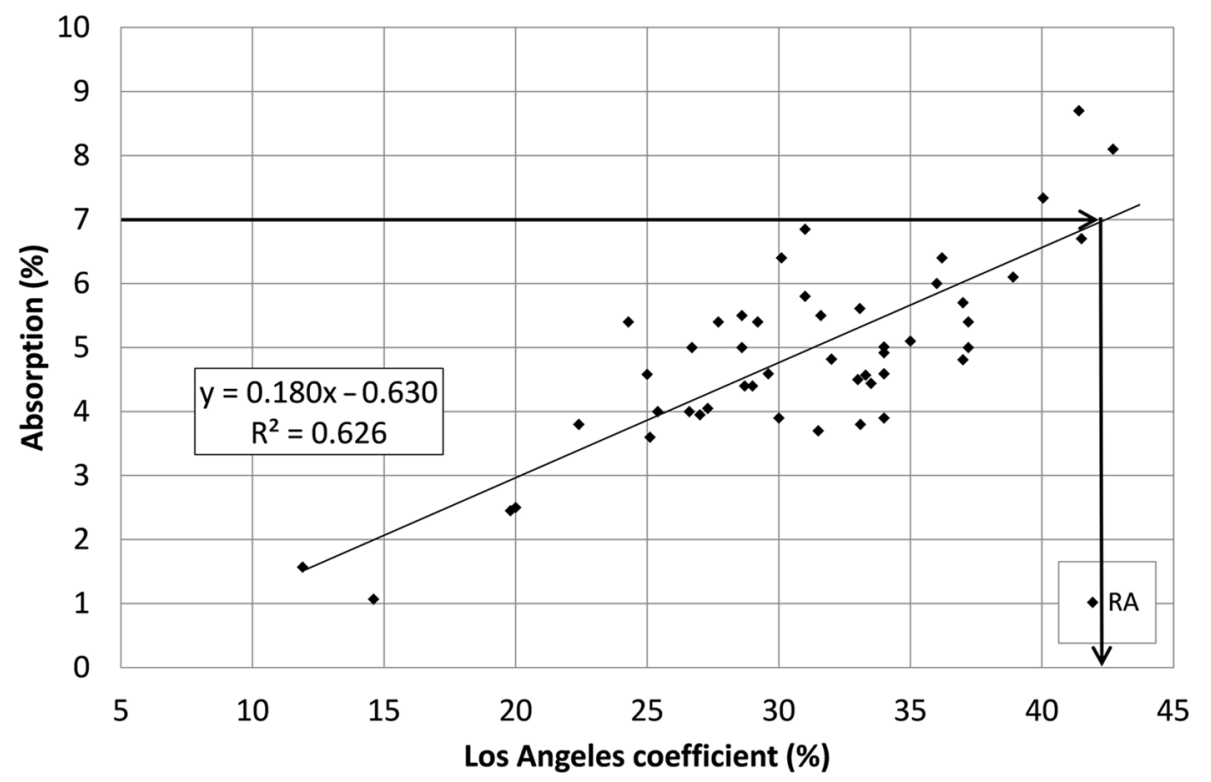

Figure 9. Water absorption vs. Los Angeles coefficient. NoTE: RA (recycled aggregate).

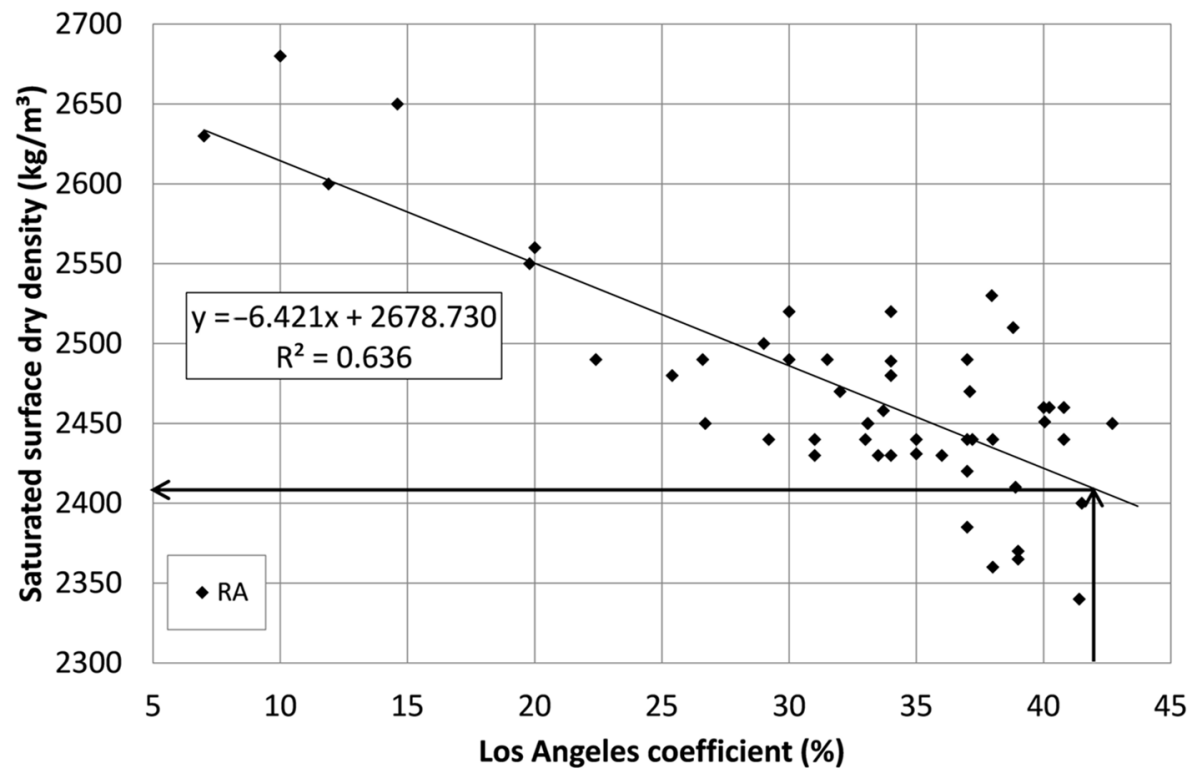

FIGURE 10. Saturated surface dry density vs. Los Angeles coefficient. NOTE: RA (recycled aggregate).

percentage of replacement of natural coarse aggregate with recycled coarse aggregate, and taking into account the recycled aggregate water absorption. In Figure 12, the same relationship is analysed as a function of saturated surface dry density. It is important to note that the cement strength grade, in all cases, was $42.5 \mathrm{MPa}$ and that the recycled concrete was made by pre-soaking or adding additional water during the mixing procedure (in general compensating up to $80 \%$ of recycled concrete coarse aggregate absorption).
In both figures, there are two groups of straight lines: one related to aggregate with absorption over $5 \%$ (Figure 11) or density under $2450 \mathrm{~kg} / \mathrm{m}^{3}$, Figure 12 (values determined according to Figure 11) ("low density recycled aggregate"-LDA) and the other showing aggregates with absorption under $5 \%$ or density over $2450 \mathrm{~kg} / \mathrm{m}^{3}$ ("high density recycled aggregate"-HDA).

In each group, there are four straight lines according to the replacement percentage: replacement of $0 \%$ or control concrete, replacement under 


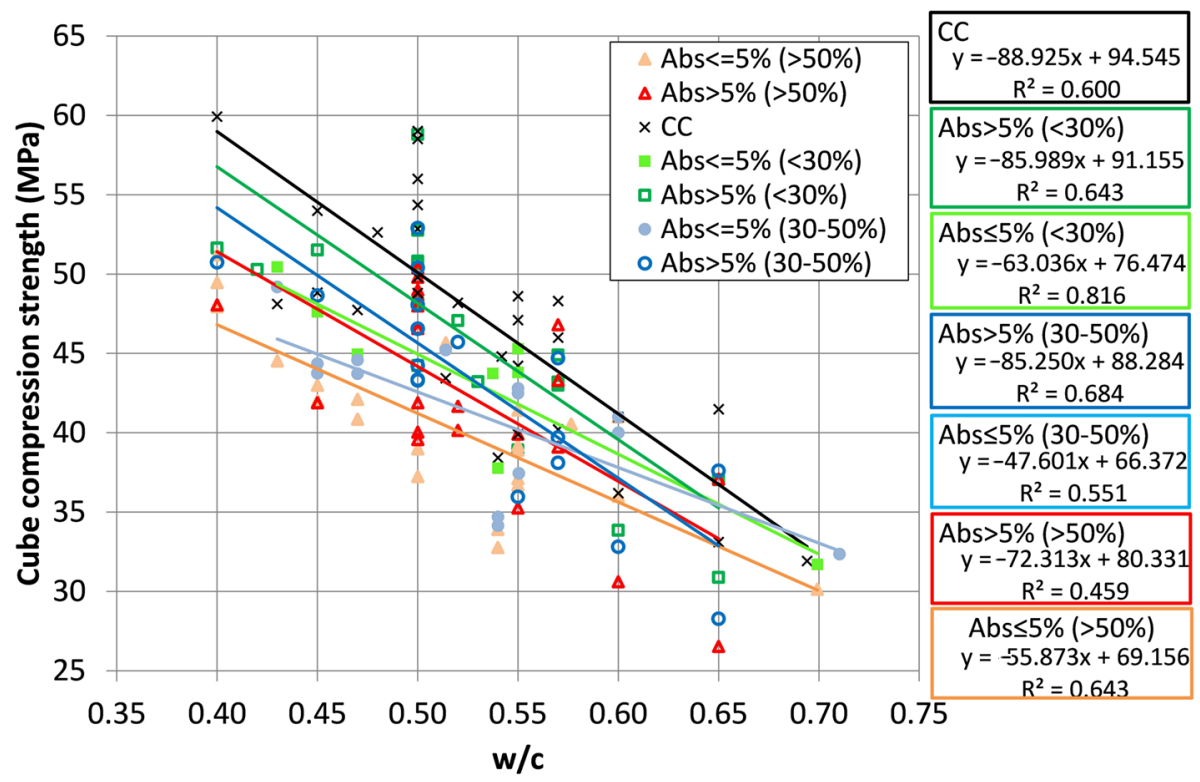

FIGURE 11. Cube compression strength vs. water/cement. Effect of recycled aggregate percentage and water absorption.

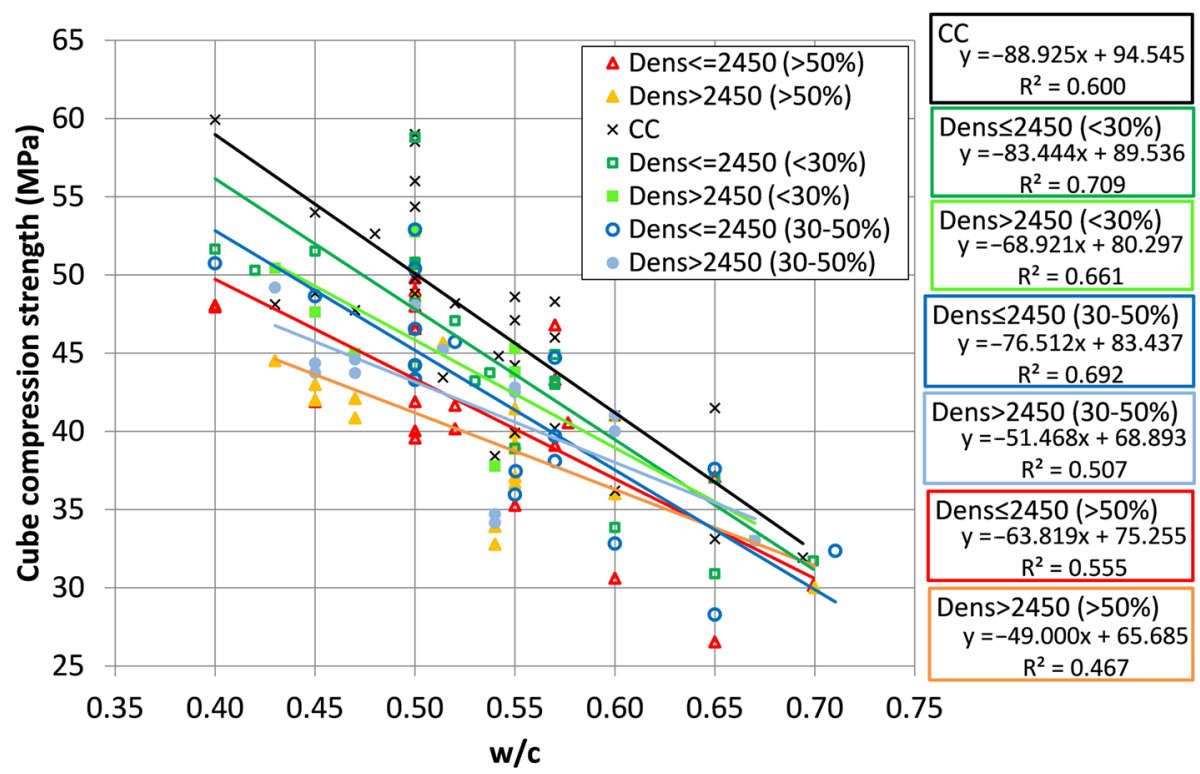

FIGURE 12. Cube compression strength vs. water/cement ratio. Effect of recycled aggregate percentage and saturated surface dry density.

$30 \%$, replacement between $30 \%$ and $50 \%$, and finally replacement over $50 \%$.

Although some scatter can be observed, in both figures the tendency is the same, which allows the following conclusions to be made.

Firstly, it can be seen that the control concrete always shows the highest strength. Additionally, in each group (HDA and LDA), the lines corresponding to high replacement percentages are always below those corresponding to low replacement percentages. This means that as the replacement ratio increases the compressive strength decreases. However, the differences are greater for lower water/cement ratios than for higher. In fact, as the w/c ratio increases the three lines of each group tend to approach each other. Therefore, for a high w/c (over 0.6), the influence of the presence of recycled aggregates on compressive strength is not significant. In these cases, the effect of the low quality of the cement paste is more significant than the presence of the recycled aggregates.

Regarding each group of lines, HDA and LDA, it can be seen that, in general, the HDA are under the LDA, which means that as the density of the recycled 
aggregates increases, or the water absorption capacity decreases, the compressive strength decreases.

The higher strength achieved with the low density or high water absorption aggregate group (LDA) compared with that of the high density or low water absorption group (HDA), is probably due to the different degree of bleeding developed. It is well known that when using pre-soaked recycled aggregates, the high water content inside the particles may result in bleeding during casting. The water inside the recycled aggregate particles may move towards the cement matrix, creating a region with an increased w/c ratio and high porosity. Furthermore, it should be remembered that recycled concrete has two interfacial transition zones (ITZ); one formed in the recycled aggregate (bond between original aggregate and old mortar) and the other newly created between the recycled aggregate (including old mortar) and the new cement paste. The bleeding process can weaken the bond between the recycled aggregate and the new cement matrix, which would weaken the strength of the concrete. When recycled aggregates have a high water absorption capacity (LDA) they can absorb a high amount of free water (when extra water is added) or retain a high amount of moisture (when pre-soaked aggregates are used). This fact would lower the initial w/c in the ITZ at early hydration. Newly formed hydrates would gradually fill this ITZ, which would effectively improve the interfacial bond between the recycled aggregate and the new cement paste. However, when recycled aggregates have a low water absorption capacity (HDA) they can't absorb a high amount of free water or retain a high amount of moisture. In this case, the degree of bleeding is high, negatively affecting the ITZ and leading to a reduction in compressive strength (119, 189, 190).

Finally, again, when the w/c ratio is low the differences between the HDA and LDA line groups are significant, although as the w/c ratio increases these differences decrease. This means that when the $\mathrm{w} / \mathrm{c}$ ratio is high (over 0.6 ), the quality of the ITZ between recycled aggregate (including old mortar) and new cement paste is not as significant as the low quality of the new cement paste, which is the "weak link in the chain".

In short, Figures 11 and 12 provide producers with useful expressions and correlations for designing recycled concrete. Taking into account recycled concrete coarse aggregate absorption (or density) and the replacement percentage, they can select a target strength, in average values, and obtain the water/cement ratio for recycled concrete production.

\section{CONCLUSIONS}

The database has made it possible to analyse the different properties of recycled concrete aggregate (aggregate recycled from concrete waste), such as density, water absorption, Los Angeles coefficient, etc. Relationships between these properties and also between some of them and the compressive strength of recycled concrete have been established. This has provided a design methodology for structural recycled concrete based on the physical-mechanical properties of recycled concrete aggregate. This methodology allows producers to establish the water/cement ratio necessary for a recycled concrete target strength, as a function of the quality of the recycled concrete coarse aggregate and the replacement percentage, whenever the mixing procedure used is the pre-soaking or compensation method (the extra water method).

Therefore, the following conclusions can be made:

1. The main difference between natural aggregate and the recycled concrete aggregate is the adhered mortar. The presence of this material decreases with the number of crushing processes, the size fraction and the original waste quality.

2. The recycled concrete aggregate presents a generally low quantity of impurities, with most standards establishing a minimum material from concrete waste of $90 \%$.

3. The recycled concrete coarse aggregate grading is similar to that of natural coarse aggregate. However, recycled sand is generally thicker than the natural fine aggregate. Furthermore, authors agree with the fact that the superficial roughness of recycled concrete aggregate is high, which also affects the loss of workability in concrete.

4. The saturated surface dry density of recycled concrete aggregate is lower than that of natural aggregate and decreases with the maximum size. When recycled concrete coarse aggregate is analysed, the average density is $2437 \mathrm{~kg} / \mathrm{m}^{3}$. When the recycled sand density is considered, the average value is $2312 \mathrm{~kg} / \mathrm{m}^{3}$. All authors agree with the fact that the adhered mortar is the cause of this decrease.

5. The natural aggregate water absorption usually ranges between $0 \%$ and $4 \%$ while the recycled concrete aggregate value is between $1.65 \%$ and $13.10 \%$. Again, the water absorption increases as the maximum aggregate size and density value decrease. Using this database it has been seen that recycled concrete coarse aggregate with water absorption values under $7 \%$ provides saturated surface dry density values over $2300 \mathrm{~kg} / \mathrm{m}^{3}$.

6. The Los Angeles coefficient of the recycled concrete aggregate is higher than that of natural aggregate. It increases with water absorption and decreases with density and maximum aggregate size. Using the database it has been seen that recycled concrete coarse aggregate 
with water absorption values under $7 \%$ provides a Los Angeles coefficient under $42 \%$.

7. Regarding compressive strength, it has been concluded that as the replacement percentage increases the compressive strength decreases. However, when the w/c ratio is over 0.6 , the influence on compressive strength of the presence of recycled aggregate is not significant. In these cases, the effect of the low quality of the new cement paste is more significant than the presence of the recycled aggregate.

8. Finally, the properties of recycled aggregates (water absorption and density value) and also the mixing process chosen to compensate their high water absorption (adding extra water or pre-soaking before mixing) influence the quality of the ITZ and therefore the concrete compressive strength. When recycled aggregates have a low water absorption capacity they can't absorb a high amount of free water and retain a high amount of moisture. In this case, the degree of bleeding is high and so the ITZ is negatively affected which leads to a reduction in compressive strength. However, when recycled aggregates have a high water absorption capacity they absorb a high amount of free water and retain a high amount of moisture. In this case the ITZ is effectively improved and the compressive strength is high.

Therefore, it can be concluded that when recycled aggregate water absorption is low (in this study under $5 \%$ ), pre-soaking or adding extra water to avoid loss in workability will negatively affect concrete compressive strength (due to the bleeding effect and through the ITZ), whereas when water absorption is high this does not occur and both of these correcting methods can be accurately used.

Finally, knowing how the recycled concrete aggregate (both percentage and quality) and the mixing procedure (pre-soaking or adding extra water) influence the recycled concrete strength of different categories (high or low water to cement ratios), enables recycled concrete to be manufactured in an accurate manner.

\section{ACKNOWLEDGMENTS}

The study is part of three projects entitled: (a) "Clean, efficient and nice construction along its life cycle (CLEAM)" funded by the Centre for the Technology and Industrial Development (CDTI) and led by the Group of Economical Interest CLEAM-CENIT, AIE comprising the country's largest construction companies (Acciona, Dragados, Ferrovial, FCC, Isolux Corsán, OHL and Sacyr) and some PYMEs (Informática 68, Quilosa and Martínez Segovia y asociados); (b) "Industrial Investigation about Concrete for a Sustainable
Market (InHorMeS)" funded by the Innovation Galician Agency; (c) "Hormigones reciclados autocompactantes robustos: reología en estado fresco y propiedades mecánicas. (Ref: BIA2014-58063-R)" funded by MINECO.

\section{REFERENCES}

1. Nik, D.O. (2005) Recycled concrete aggregates. Cem. Concr. Compos., 27 [2], 315-318. http://dx.doi.org/10.1016/j. cemconcomp.2004.02.020.

2. Meyer, C. (2009) The greening of the concrete industry. Cem. Concr. Compos., 31 [8], 601-605. http://dx.doi.org/ 10.1016/j.cemconcomp.2008.12.010.

3. Abbas, A.; Fathifazl, G.; Fournier, B.; Isgor, O.B.; Zavadil, R.; Razaqpur, A.G.; Foo, S. (2009) Quantification of the residual mortar content in recycled concrete aggregates by image analysis. Mater. Charact., 60 [7], 716-728. http:// dx.doi.org/10.1016/j.matchar.2009.01.010.

4. Agrela, F.; Sánchez de Juan, M.; Ayuso, J.; Geraldes, V.L.; Jiménez, J.R. (2011) Limiting properties in the characterisation of mixed recycled aggregates for use in the manufacture of concrete. Constr. Build. Mater., 25 [10], 3950-3955. http://dx.doi.org/10.1016/j.conbuildmat.2011.04.027.

5. Ajdukiewicz, A.; Kliszczewicz, A. (2002) Influence of recycled aggregates on mechanical properties of HS/HPC. Cem. Concr. Compos., 24 [2], 269-279. http://dx.doi.org/10.1016/ S0958-9465(01)00012-9.

6. Akbarnezhad, A.; Ong, K.C.G.; Tam, C.T.; Zhang, M.H. (2013) Effects of the parent concrete properties and crushing procedure on the properties of coarse recycled concrete aggregates. J. Mater. Civ. Eng., 25 [12], 1795-1802. http:// dx.doi.org/10.1061/(ASCE)MT.1943-5533.0000789.

7. Akbarnezhad, A.; Ong, K.C.G.; Zhang, M.H.; Tam, C.T.; Foo, T.W.J. (2011) Microwave-assisted beneficiation of recycled concrete aggregates. Constr. Build. Mater., 25 [8], 3469-3479. http://dx.doi.org/10.1016/j.conbuildmat.2011. 03.038 .

8. Angulo, S.C.; Carrijo, P.M.; Figueiredo, A.D.; Chaves, A.P.; John, V.M. (2010) On the classification of mixed construction and demolition waste aggregate by porosity and its impact on the mechanical performance of concrete. Mater. Struct., 43 [4], 519-528. http://dx.doi.org/10.1617/ s11527-009-9508-9.

9. Ann, K.Y.; Moon, H.Y.; Kim, Y.B.; Ryou, J. (2008) Durability of recycled aggregate concrete using pozzolanic materials. Waste Manage., 28 [6], 993-999. http://dx.doi. org/10.1016/j.wasman.2007.03.003.

10. Bairagi, N.K.; Ravande, K.; Pareek, V.K. (1993) Behaviour of concrete with different proportions of natural and recycled aggregates. Resour. Conserv. Recycl., 9 [1-2], 109-126. http://dx.doi.org/10.1016/0921-3449(93)90036-F.

11. Bairagi, N.K.; Vidyadhara, H.S.; Ravande, K. (1990) Mix design procedure for recycled aggregate concrete. Constr. Build. Mater., 4 [4], 188-193. http://dx.doi.org/10.1016/ 0950-0618(90)90039-4.

12. Barbudo, A.; De Brito, J.; Evangelista, L.; Bravo, M.; Agrela, F. (2013) Influence of water-reducing admixtures on the mechanical performance of recycled concrete. $J$. Clean. Prod., 59, 93-98. http://dx.doi.org/10.1016/j.jclepro. 2013.06.022.

13. Barra, M.; Vázquez, E. (1997) Particularidades do proceso de carbonatação em concretos de agregado reciclado. IV Congreso Iberoamericano de Patología de las Construcciones, VI Congreso de Control y Calidad, Octubre 1997, Brasil.

14. Batayneh, M.; Marie, I.; Asi, I. (2007) Use of selected waste materials in concrete mixes. Waste Manage., 27 [12], 1870-1876. http://dx.doi.org/10.1016/j.wasman.2006. 07.026.

15. Belin, P.; Habert, G.; Thiery, M.; Roussel, N. (2014) Cement paste content and water absorption of recycled concrete coarse aggregates. Mater. Struct., 47 [9], 1451-1465. http:// dx.doi.org/10.1617/s11527-013-0128-z. 
16. Beltrán, M.G.; Barbudo, A.; Agrela, F.; Galvín, A.P.; Jiménez, J.R. (2014) Effect of cement addition on the properties of recycled concretes to reach control concretes strengths. J. Clean. Prod., 79, 124-133. http://dx.doi. org/10.1016/j.jclepro.2014.05.053.

17. Berndt, M.L. (2009) Properties of sustainable concrete containing fly ash, slag and recycled concrete aggregate. Constr. Build. Mater., 23 [7], 2606-2613. http://dx.doi.org/ 10.1016/j.conbuildmat.2009.02.011.

18. Bhikshma, V.; Kishore, R. (2010) Development of stress strain curves for recycled aggregate concrete. Asian J. Civ. Eng., 11 [2], 253-261.

19. Brand, A.S.; Roesler, J.R.; Salas, A. (2015) Initial moisture and mixing effects on higher quality recycled coarse aggregate concrete. Constr. Build. Mater., 79, 83-89. http:// dx.doi.org/10.1016/j.conbuildmat.2015.01.047.

20. Butler, L.; Tighe, S.L.; West, J.S. (2013) Guidelines for selection and use of coarse recycled-concrete aggregates in structural concrete. J. Transp. Res. Board, 2335, 3-12. http://dx.doi.org/10.3141/2335-01.

21. Buyle-Bodin, F.; Hadjieva-Zaharieva, R. (2002) Influence of industrially produced recycled aggregates on flow properties of concrete. Mater. Struct., 35 [252 SPEC.], 504-509. http://dx.doi.org/10.1007/BF02483138.

22. Cabral, A.E.B.; Schalch, V.; Molin, D.C.C.D.; Ribeiro, J.L.D. (2010) Mechanical properties modelling of recycled aggregate concrete. Constr. Build. Mater., 24 [4], 421-430. http://dx.doi.org/10.1016/j.conbuildmat.2009.10.011.

23. Castaño, J.O.; Domingo, A.; Lázaro, C. (2009) A study on drying shrinkage and creep of recycled concrete aggregate. Proceedings of the International Association for Shell and Spatial Structures (IASS) Symposium 2009, Valencia.

24. Casuccio, M.; Torrijos, M.C.; Giaccio, G.; Zerbino, R. (2008) Failure mechanism of recycled aggregate concrete. Constr. Build. Mater., 22 [7], 1500-1506. http://dx.doi.org/10.1016/j. conbuildmat.2007.03.032

25. Chakradhara Rao, M.; Bhattacharyya, S.K.; Barai, S.V. (2011) Behaviour of recycled aggregate concrete under drop weight impact load. Constr. Build. Mater., 25 [1], 69-80. http://dx.doi.org/10.1016/j.conbuildmat.2010.06.055.

26. Chakradhara Rao, M.; Bhattacharyya, S.K.; Barai, S.V. (2011) Influence of field recycled coarse aggregate on properties of concrete. Mater. Struct., 44 [1], 205-220. http:// dx.doi.org/10.1617/s11527-010-9620-x.

27. Chen, A.; Wang, J.; Ge, Z. (2011) Experimental study on the fundamental characteristics of recycled concrete. $A d v$. Mater. Res., 295-297, 958-961. http://dx.doi.org/10.4028/ www.scientific.net/amr.295-297.958

28. Chen, Z.; Huang, K.; Zhang, X.; Xue, J. (2010) Experimental research on the flexural strength of recycled coarse aggregate concrete. International conference on mechanic automation and control engineering (MACE), Wuhan, China 1041-1043.

29. Corinaldesi, V.; Moriconi, G. (2012) Recycled aggregate concretes for structural applications: from investigation to design. Adv. Mater. Res., 548, 209-214. http://dx.doi.org/ 10.4028/www.scientific.net/AMR.548.209.

30. Corinaldesi, V. (2011) Structural concrete prepared with coarse recycled concrete aggregate: From investigation to design. Adv. Civ. Eng., 2011. http://dx.doi.org/10.1155/2011/ 283984.

31. Corinaldesi, V.; Letelier, V.; Moriconi, G. (2011) Behaviour of beam-column joints made of recycled-aggregate concrete under cyclic loading. Constr. Build. Mater., 25 [4], 1877-1882. http://dx.doi.org/10.1016/j.conbuildmat.2010.11.072.

32. Corinaldesi, V. (2010) Mechanical and elastic behaviour of concretes made of recycled-concrete coarse aggregates. Constr. Build. Mater., 24 [9], 1616-1620. http://dx.doi.org/ 10.1016/j.conbuildmat.2010.02.031

33. Corinaldesi, V.; Moriconi, G. (2010) Recycling of rubble from building demolition for low-shrinkage concretes. Waste Manage., 30 [4], 655-659. http://dx.doi.org/10.1016/j. wasman.2009.11.026.

34. Corinaldesi, V.; Moriconi, G. (2009) Behaviour of cementitious mortars containing different kinds of recycled aggregate. Constr. Build. Mater., 23 [1], 289-294. http://dx.doi. org/10.1016/j.conbuildmat.2007.12.006.
35. Corinaldesi, V.; Moriconi, G. (2009) Influence of mineral additions on the performance of $100 \%$ recycled aggregate concrete. Constr. Build. Mater., 23 [8], 2869-2876. http:// dx.doi.org/10.1016/j.conbuildmat.2009.02.004.

36. Courard, L.; Michel, F.; Delhez, P. (2010) Use of concrete road recycled aggregates for roller compacted concrete. Constr. Build. Mater., 24 [3], 390-395. http://dx.doi. org/10.1016/j.conbuildmat.2009.08.040.

37. Cui, H.Z.; Shi, X.; Memon, S.A.; Xing, F.; Tang, W. (2015) Experimental study on the influence of water absorption of recycled coarse aggregates on properties of the resulting concretes. J. Mater. Civ. Eng., 27 [4]. http://dx.doi.org/ $10.1061 /($ asce)mt.1943-5533.0001086.

38. De Juan, M.S. (2005) Estudio sobre la utilización de árido reciclado para la fabricación de Hormigón Estructural. PhD Dissertation, Polytechnic University of Madrid, Spain.

39. De Oliveira, M.B.; Vázquez, E. (1996) The influence of retained moisture in aggregates from recycling on the properties of new hardened concrete. Waste Manage., 16 [1-3], 113-117. http://dx.doi.org/10.1016/S0956-053X(96)00033-5.

40. Debieb, F.; Courard, L.; Kenai, S.; Degeimbre, R. (2010) Mechanical and durability properties of concrete using contaminated recycled aggregates. Cem. Concr. Compos., 32 [6], 421-426. http://dx.doi.org/10.1016/j.cemconcomp. 2010.03.004

41. Debieb, F.; Courard, L.; Kenai, S.; Degeimbre, R. (2009) Roller compacted concrete with contaminated recycled aggregates. Constr. Build. Mater., 23 [11], 3382-3387. http:// dx.doi.org/10.1016/j.conbuildmat.2009.06.031.

42. Di Maio, A.A.; Traversa, L.P. (2003) Evaluation of recycled concrete by means of non destructive tests. [Evaluación de hormigones reciclados mediante ensayos no destructivos] Mater. Construcc., 53 [271-272], 37-46. http://dx.doi. org/10.3989/mc.2003.v53.i271-272.287.

43. Djerbi Tegguer, A. (2012) Determining the water absorption of recycled aggregates utilizing hydrostatic weighing approach. Constr. Build. Mater., 27 [1], 112-116. http:// dx.doi.org/10.1016/j.conbuildmat.2011.08.018.

44. Domingo-Cabo, A.; Lázaro, C.; López-Gayarre, F.; SerranoLópez, M.A.; Serna, P.; Casta-o-Tabares, J.O. (2009) Creep and shrinkage of recycled aggregate concrete. Constr. Build. Mater., 23 [7], 2545-2553. http://dx.doi.org/10.1016/j. conbuildmat.2009.02.018

45. Duan, Z.H.; Poon, C.S. (2014) Properties of recycled aggregate concrete made with recycled aggregates with different amounts of old adhered mortars. Mater. Design, 58, 19-29. http://dx.doi.org/10.1016/j.matdes.2014.01.044.

46. Eguchi, K.; Teranishi, K.; Nakagome, A.; Kishimoto, H.; Shinozaki, K.; Narikawa, M. (2007) Application of recycled coarse aggregate by mixture to concrete construction. Constr. Build. Mater., 21 [7], 1542-1551. http://dx.doi.org/10.1016/j. conbuildmat.2005.12.023

47. Etxeberria, M.; Marí, A.R.; Vázquez, E. (2007) Recycled aggregate concrete as structural material. Mater. Struct. 40 [5], 529-541. http://dx.doi.org/10.1617/s11527-006-9161-5.

48. Etxeberria, M.; Vázquez, E.; Marí, A.; Barra, M. (2007) Influence of amount of recycled coarse aggregates and production process on properties of recycled aggregate concrete. Cem. Concr. Res., 37 [5], 735-742. http://dx.doi. org/10.1016/j.cemconres.2007.02.002.

49. Evangelista, L.; de Brito, J. (2007) Mechanical behaviour of concrete made with fine recycled concrete aggregates. Cem. Concr. Compos., 29 [5], 397-401. http://dx.doi.org/10.1016/j. cemconcomp.2006.12.004.

50. Faleschini, F.; Jiménez, C.; Barra, M.; Aponte, D.; Vázquez, E.; Pellegrino, C. (2014) Rheology of fresh concretes with recycled aggregates. Constr. Build. Mater., 73, 407-416. http://dx.doi.org/10.1016/j.conbuildmat.2014.09.068.

51. Ferreira, L.; De Brito, J.; Barra, M. (2011) Influence of the pre-saturation of recycled coarse concrete aggregates on concrete properties. Mag. Concr. Res., 63 [8], 617-627. http://dx.doi.org/10.1680/macr.2011.63.8.617.

52. Folino, P.; Xargay, H. (2014) Recycled aggregate concrete - mechanical behavior under uniaxial and triaxial compression. Constr. Build. Mater., 56, 21-31. http://dx.doi. org/10.1016/j.conbuildmat.2014.01.073. 
53. Fonseca, N.; de Brito, J.; Evangelista, L. (2011) The influence of curing conditions on the mechanical performance of concrete made with recycled concrete waste. Cem. Concr. Compos., 33 [6], 637-643. http://dx.doi.org/10.1016/j. cemconcomp.2011.04.002.

54. Garg, A.; Koster, G.; Rühl, M. (1998) Implementation of long term measurements at a building made of concrete with aggregate derived from concrete rubble.

55. Gokce, A.; Nagataki, S.; Saeki, T.; Hisada, M. (2011) Identification of frost-susceptible recycled concrete aggregates for durability of concrete. Constr. Build. Mater., 25 [5], 2426-2431. http://dx.doi.org/10.1016/j.conbuildmat.2010. 11.054 .

56. Gomes, M.; de Brito, J.; Bravo, M. (2014) Mechanical performance of structural concrete with the incorporation of coarse recycled concrete and ceramic aggregates. J. Mater. Civ. Eng., 26 [10]. http://dx.doi.org/10.1061/(asce) mt.1943-5533.0000973.

57. Gómez-Soberón, J.M.V. (2002) Porosity of recycled concrete with substitution of recycled concrete aggregate: An experimental study. Cem. Concr. Res., 32 [8], 1301-1311. http://dx.doi.org/10.1016/S0008-8846(02)00795-0.

58. González, A.; Etxeberria, M. (2014) Experimental analysis of properties of high performance recycled aggregate concrete. Constr. Build. Mater., 52, 227-235. http://dx.doi. org/10.1016/j.conbuildmat.2013.11.054.

59. González-Fonteboa, B.; Martínez-Abella, F.; Herrador, M.F.; Seara-Paz, S. (2012) Structural recycled concrete: Behaviour under low loading rate. Constr Build Mater. 28 [1], 111-116. http://dx.doi.org/10.1016/j.conbuildmat. 2011.08.010

60. González, B.; Martínez, F.; Carro, D.; Seara, S. (2011) Stress-strain relationship in axial compression for concrete using recycled saturated coarse aggregate. Constr. Build. Mater., 25 [5], 2335-2342. http://dx.doi.org/10.1016/j. conbuildmat.2010.11.031.

61. González-Fonteboa, B.; Martínez -Abella, F. (2005) Recycled aggregates concrete: Aggregate and mix properties. [Hormigones con áridos reciclados: Estudio de propiedades de los áridos y de las mezclas] Mater. Construcc. 55 [279], 53-66. http://dx.doi.org/10.3989/mc.2005.v55. i279.198.

62. Grdic, Z.J.; Toplicic-Curcic, G.A.; Despotovic, I.M.; Ristic, N.S. (2010) Properties of self-compacting concrete prepared with coarse recycled concrete aggregate. Constr. Build. Mater., 24 [7], 1129-1133. http://dx.doi.org/10.1016/j. conbuildmat.2009.12.029.

63. Grübl, P.; Nealen, A. (1998) Construction of an office building using concrete made from recycled demolition material. Aus Darmstadt Concr., 13.

64. Hansen, T.C.; Narud, H. (1983) Strength of recycled concrete made from crushed concrete coarse aggregate. Concr. Int., 5 [1], 79-83.

65. Hincapié Henao, Á.M.; Aguja López, E.A. (2003) Agregado reciclado para morteros Universidad EAFIT, 39 [132], 76-89.

66. Ho, N.Y.; Lee, Y.P.K.; Lim, W.F.; Zayed, T.; Chew, K.C.; Low, G.L.; et al. (2013) Efficient utilization of recycled concrete aggregate in structural concrete. J. Mater. Civ. Eng., 25 [3], 318-327. http://dx.doi.org/10.1061/(ASCE) MT.1943-5533.0000587.

67. Ismail, S.; Ramli, M. (2013) Engineering properties of treated recycled concrete aggregate (RCA) for structural applications. Constr. Build. Mater., 44, 464 476. http:// dx.doi.org/10.1016/j.conbuildmat.2013.03.014.

68. Jiménez, C.; Aponte, D.; Vázquez, E.; Barra, M.; Valls, S. (2013) Equivalent mortar volume (EMV) method for proportioning recycled aggregate concrete: Validation under the spanish context and its adaptation to bolomey methodology for concrete proportioning. Mater. Construcc., 63 [311] , 341-360. http://dx.doi.org/10.3989/mc.2012.01112.

69. Jo, B.; Park, S.; Park, J. (2008) Mechanical properties of polymer concrete made with recycled PET and recycled concrete aggregates. Constr. Build. Mater., 22 [12], 2281-2291. http://dx.doi.org/10.1016/j.conbuildmat.2007. 10.009 .
70. Kalaiarasu, S.M.; Subramanian, K. (2006) Properties of recycled aggregate concrete with silica fume. J. Appl. Sci., 6 [14], 2956-2958. http://dx.doi.org/10.3923/jas.2006.2956. 2958.

71. Katz, A. (2004) Treatments for the improvement of recycled aggregate. J. Mater. Civ. Eng., 16 [6], 597-603. http:// dx.doi.org/10.1061/(ASCE)0899-1561(2004)16:6(597).

72. Katz, A. (2003) Properties of concrete made with recycled aggregate from partially hydrated old concrete. Cem. Concr. Res., 33 [5], 703-711. http://dx.doi.org/10.1016/ S0008-8846(02)01033-5.

73. Kebaïli, O.; Mouret, M.; Arabia, N.; Cassagnabere, F. (2015) Adverse effect of the mass substitution of natural aggregates by air-dried recycled concrete aggregates on the self-compacting ability of concrete: Evidence and analysis through an example. J. Clean. Prod., 87 [1], 752-761. http:// dx.doi.org/10.1016/j.jclepro.2014.10.077.

74. Khatib, J.M. (2005) Properties of concrete incorporating fine recycled aggregate. Cem. Concr. Res., 35 [4], 763-769. http://dx.doi.org/10.1016/j.cemconres.2004.06.017.

75. Khoshkenari, A.G.; Shafigh, P.; Moghimi, M.; Mahmud, H.B. (2014) The role of $0-2 \mathrm{~mm}$ fine recycled concrete aggregate on the compressive and splitting tensile strengths of recycled concrete aggregate concrete. Mater. Design, 64, 345-354. http://dx.doi.org/10.1016/j.matdes.2014.07.048.

76. Kim, K.; Shin, M.; Cha, S. (2013) Combined effects of recycled aggregate and fly ash towards concrete sustainability. Constr. Build. Mater., 48, 499-507. http://dx.doi. org/10.1016/j.conbuildmat.2013.07.014.

77. Kishore, R. (2007) Influence of recycled aggregate on flexural behaviour of reinforced concrete beams. http://www. claisse.info/supplementary\%20papers/kishor_full_text.pdf.

78. Knaack, A.M.; Kurama, Y.C. (2012) Rheological and mechanical behavior of concrete mixtures with recycled concrete aggregates. Proceedings of the ASCE Structures Congress, Chicago, Illinois. http://dx.doi.org/10.1061/ 9780784412367.198

79. Kong, D.; Lei, T.; Zheng, J.; Ma, C.; Jiang, J.; Jiang, J. (2010) Effect and mechanism of surface-coating pozzolanics materials around aggregate on properties and ITZ microstructure of recycled aggregate concrete. Constr. Build. Mater., 24 [5], 701-708. http://dx.doi.org/10.1016/j. conbuildmat.2009.10.038.

80. Kou, S.; Poon, C. (2015) Effect of the quality of parent concrete on the properties of high performance recycled aggregate concrete. Constr. Build. Mater., 77, 501-508. http://dx.doi.org/10.1016/j.conbuildmat.2014.12.035.

81. Kou, S.; Poon, C. (2013) Long-term mechanical and durability properties of recycled aggregate concrete prepared with the incorporation of fly ash. Cem. Concr. Compos., 37 [1], 12-19. http://dx.doi.org/10.1016/j.cemconcomp.2012. 12.011 .

82. Kou, S.C.; Poon, C.S. (2012) Enhancing the durability properties of concrete prepared with coarse recycled aggregate. Constr. Build. Mater., 35, 69-76. http://dx.doi. org/10.1016/j.conbuildmat.2012.02.032.

83. Kou, S.; Poon, C.; Etxeberria, M. (2011) Influence of recycled aggregates on long term mechanical properties and pore size distribution of concrete. Cem. Concr. Compos., 33 [2], 286-291. http://dx.doi.org/10.1016/j.cemconcomp. 2010.10 .003

84. Kou, S.; Poon, C. (2010) Properties of concrete prepared with PVA-impregnated recycled concrete aggregates. Cem. Concr. Compos., 32 [8], 649-654. http://dx.doi.org/10.1016/j. cemconcomp.2010.05.003.

85. Kou, S.C.; Poon, C.S. (2009) Properties of self-compacting concrete prepared with coarse and fine recycled concrete aggregates. Cem. Concr. Compos., 31 [9], 622-627. http:// dx.doi.org/10.1016/j.cemconcomp.2009.06.005.

86. Kou, S.; Poon, C. (2009) Properties of concrete prepared with crushed fine stone, furnace bottom ash and fine recycled aggregate as fine aggregates. Constr. Build. Mater., 23 [8], 2877-2886. http://dx.doi.org/10.1016/j.conbuildmat. 2009.02.009.

87. Kou, S.C.; Poon, C.S.; Chan, D. (2008) Influence of fly ash as a cement addition on the hardened properties of recycled 
aggregate concrete. Mater. Struct., 41 [7], 1191-1201. http:// dx.doi.org/10.1617/s11527-007-9317-y.

88. Kou, S.C.; Poon, C.S.; Dixon, C. (2007) Influence of fly ash as cement replacement on the properties of recycled aggregate concrete. J. Mater. Civ. Eng., 19 [9], 709-717. http:// dx.doi.org/10.1061/(ASCE)0899-1561(2007)19:9(709).

89. Leite, M.B.; Figueire Do Filho, J.G.L.; Lima, P.R.L. (2013) Workability study of concretes made with recycled mortar aggregate. Mater. Struct., 46 [10], 1765-1778. http://dx.doi. org/10.1617/s11527-012-0010-4.

90. Levy, S.M.; Helene, P. (2004) Durability of recycled aggregates concrete: A safe way to sustainable development. Cem. Concr. Res., 34 [11], 1975-1980. http://dx.doi. org/10.1016/j.cemconres.2004.02.009.

91. Li, W.; Xiao, J.; Sun, Z.; Kawashima, S.; Shah, S.P. (2012) Interfacial transition zones in recycled aggregate concrete with different mixing approaches. Constr. Build. Mater., 35, 1045-1055. http://dx.doi.org/10.1016/j.conbuildmat.2012. 06.022 .

92. Li, Y.; Tao, J.; Lei, T.; Xie, J. (2011) Experimental study on compressive strength of recycled concrete. Adv. Mater. Res., 261-263, 75-78. http://dx.doi.org/10.4028/www.scientific.net/amr.261-263.75.

93. Li, J.; Xiao, H.; Zhou, Y. (2009) Influence of coating recycled aggregate surface with pozzolanic powder on properties of recycled aggregate concrete. Constr. Build. Mater., 23 [3], 1287-1291. http://dx.doi.org/10.1016/j.conbuildmat. 2008.07.019

94. Lima, C.; Caggiano, A.; Faella, C.; Martinelli, E.; Pepe, M.; Realfonzo, R. (2013) Physical properties and mechanical behaviour of concrete made with recycled aggregates and fly ash. Constr. Build. Mater., 47, 547-559. http://dx.doi. org/10.1016/j.conbuildmat.2013.04.051.

95. Limbachiya, M.; Meddah, M.S.; Ouchagour, Y. (2012) Use of recycled concrete aggregate in fly-ash concrete. Constr. Build. Mater., 27 [1], 439-449. http://dx.doi.org/10.1016/j. conbuildmat.2011.07.023.

96. Lin, Y.; Tyan, Y.; Chang, T.; Chang, C. (2004) An assessment of optimal mixture for concrete made with recycled concrete aggregates. Cem. Concr. Res., 34 [8], 1373-1380. http://dx.doi.org/10.1016/j.cemconres.2003.12.032.

97. López Gayarre, F.; López-Colina Pérez, C.; Serrano López, M.A.; Domingo Cabo, A. (2014) The effect of curing conditions on the compressive strength of recycled aggregate concrete. Constr. Build. Mater., 53, 260-266. http://dx.doi. org/10.1016/j.conbuildmat.2013.11.112.

98. López-Gayarre, F.; Serna, P.; Domingo-Cabo, A.; SerranoLópez, M.A.; López-Colina, C. (2009) Influence of recycled aggregate quality and proportioning criteria on recycled concrete properties. Waste Manage., 29 [12], 3022-3028. http://dx.doi.org/10.1016/j.wasman.2009.07.010.

99. Malešev, M.; Radonjanin, V.; Marinković, S. (2010) Recycled concrete as aggregate for structural concrete production. Sustainability, 2 [5], 1204-1225. http://dx.doi.org/10.3390/ su2051204.

100. Manzi, S.; Mazzotti, C.; Bignozzi, M.C. (2013) Short and long-term behavior of structural concrete with recycled concrete aggregate. Cem. Concr. Compos., 37 [1], 312-318. http://dx.doi.org/10.1016/j.cemconcomp.2013.01.003.

101. Matias, D.; De Brito, J.; Rosa, A.; Pedro, D. (2013) Mechanical properties of concrete produced with recycled coarse aggregates - influence of the use of superplasticizers. Constr. Build. Mater., 44, 101-109. http://dx.doi.org/ 10.1016/j.conbuildmat 2013.03 .011$.

102. Mefteh, H.; Kebaïli, O.; Oucief, H.; Berredjem, L.; Arabi, N. (2013) Influence of moisture conditioning of recycled aggregates on the properties of fresh and hardened concrete. J. Clean. Prod., 54, 282-288. http://dx.doi.org/10.1016/j. jclepro.2013.05.009

103. Miranda, L.F.R.; Selmo, S.M.S. (2006) CDW recycled aggregate renderings: Part I - analysis of the effect of materials finer than $75 \mu \mathrm{m}$ on mortar properties. Constr. Build. Mater., 20 [9], 615-624. http://dx.doi.org/10.1016/j. conbuildmat.2005.02.025

104. Morohashi, N.; Sakurada, T. (2008) An experimental study on the bond splitting strength of reinforced concrete beams with a mixture of recycled aggregate and normal aggregate. J. Struct. Constr. Eng., 73 [634], 2175-2183. http://dx.doi.org/10.3130/aijs.73.2175.

105. Nagataki, S.; Gokce, A.; Saeki, T.; Hisada, M. (2004) Assessment of recycling process induced damage sensitivity of recycled concrete aggregates. Cem. Concr. Res., 34 [6], 965-971. http://dx.doi.org/10.1016/j.cemconres.2003.11.008.

106. Ortega, N.F.; Moro, J.M.; Meneses, R.; Aveldaño, R.R. (2010) Comportamiento dinámico de vigas de hormigón reciclado con sus armaduras corroídas. VI Congreso Internacional sobre Patología y Recuperación de Estructuras, June 2010, Argentina.

107. Otsuki, N.; Miyazato, S.; Yodsudjai, W. (2003) Influence of recycled aggregate on interfacial transition zone, strength, chloride penetration and carbonation of concrete. J. Mater. Civ. Eng., 15 [5], 443-451. http://dx.doi.org/10.1061/(ASCE) 0899-1561(2003)15:5(443).

108. Padmini, A.K.; Ramamurthy, K.; Mathews, M.S. (2009) Influence of parent concrete on the properties of recycled aggregate concrete. Constr. Build. Mater., 23 [2], 829-836. http://dx.doi.org/10.1016/j.conbuildmat.2008.03.006.

109. Park, S.B.; Seo, D.S.; Lee, J. (2005) Studies on the sound absorption characteristics of porous concrete based on the content of recycled aggregate and target void ratio. Cem. Concr. Res., 35 [9], 1846-1854. http://dx.doi.org/10.1016/j. cemconres.2004.12.009.

110. Pedro, D.; De Brito, J.; Evangelista, L. (2014) Influence of the use of recycled concrete aggregates from different sources on structural concrete. Constr. Build. Mater., 71, 141-151. http://dx.doi.org/10.1016/j.conbuildmat.2014.08.030.

111. Pelufo, M.J.; Domingo, A.; Ulloa, V.A.; Vergara, N.N. (2009) Analysis of moisture state of recycled coarse aggregate and its influence on compression strength of the concrete. Proceedings of the International Association for Shell and Spatial Structures (IASS) Symposium 2009, Valencia.

112. Peng, G.F.; Liu, Q.B.; Guo, Z.B.; Hou, Q.X.; Cao, S.Q.; Zhang, J.F. (2011) Mechanical properties and permeability of recycled aggregate concrete at low water/binder ratio.

113. Pepe, M.; Toledo Filho, R.D.; Koenders, E.A.B.; Martinelli, E. (2014) Alternative processing procedures for recycled aggregates in structural concrete. Constr. Build. Mater., 69, 124-132. http://dx.doi.org/10.1016/j. conbuildmat.2014.06.084.

114. Pereira, P.; Evangelista, L.; de Brito, J. (2012) The effect of superplasticizers on the mechanical performance of concrete made with fine recycled concrete aggregates. Cem. Concr. Compos., 34, 1044-1052. http://dx.doi.org/10.1016/j. cemconcomp.2012.06.009.

115. Pereira-De-Oliveira, L.A · Nepomuceno, M.C.S · CastroGomes, J.P.; Vila, M.F.C. (2014) Permeability properties of self-compacting concrete with coarse recycled aggregates. Constr. Build. Mater., 51, 113-120. http://dx.doi.org/ 10.1016/j.conbuildmat.2013.10.061.

116. Poon, C.S.; Kou, S.C.; Lam, L. (2007) Influence of recycled aggregate on slump and bleeding of fresh concrete. Mater. Struct., 40 [9], 981-988. http://dx.doi.org/10.1617/ s11527-006-9192-y.

117. Poon, C.S.; Chan, D. (2006) Feasible use of recycled concrete aggregates and crushed clay brick as unbound road sub-base. Constr. Build. Mater., 20 [8], 578-585. http:// dx.doi.org/10.1016/j.conbuildmat.2005.01.045.

118. Poon, C.S.; Chan, D. (2006) Paving blocks made with recycled concrete aggregate and crushed clay brick. Constr. Build. Mater., 20 [8], 569-577. http://dx.doi.org/10.1016/j. conbuildmat.2005.01.044.

119. Poon, C.S.; Shui, Z.H.; Lam, L. (2004) Effect of microstructure of ITZ on compressive strength of concrete prepared with recycled aggregates. Constr. Build. Mater., 18 [6], 461-468. http://dx.doi.org/10.1016/j.conbuildmat. 2004.03 .005

120. Poon, C.S.; Shui, Z.H.; Lam, L.; Fok, H.; Kou, S.C. (2004) Influence of moisture states of natural and recycled aggregates on the slump and compressive strength of concrete. Cem. Concr. Res., 34 [1], 31-36. http://dx.doi.org/10.1016/ S0008-8846(03)00186-8. 
121. Qasrawi, H.; Marie, I. (2013) Towards better understanding of concrete containing recycled concrete aggregate. $A d v$. Mater. Sci. Eng., 2013. http://dx.doi.org/10.1155/2013/636034.

122. Rahal, K. (2007) Mechanical properties of concrete with recycled coarse aggregate. Build. Environ., 42 [1], 407-415. http://dx.doi.org/10.1016/j.buildenv.2005.07.033.

123. Randonjanin, V.; Malešev, M.; Marinkovi, S. (2012) Recycled concrete as aggregate for structural concrete production. The Masterbuilder, May 2012, 58-72.

124. Ravindrarajah Sri, R.; Loo, Y.H.; Tam, C.T. (1987) Recycled concrete as fine and coarse aggregates in concrete. Mag. Concr. Res., 39 [141], 214-220. http://dx.doi.org/10.1680/ macr.1987.39.141.214.

125. Ravindrarajah Sri, R.; Tam, C.T. (1985) Properties of concrete made with crushed concrete as coarse aggregate. Mag. Concr. Res., 37 [130], 29-38. http://dx.doi.org/10.1680/ macr.1985.37.130.29

126. Safiuddin, M.; Alengaram, U.J.; Salam, M.A.; Jumaat, M.Z.; Jaafar, F.F.; Saad, H.B. (2011) Properties of highworkability concrete with recycled concrete aggregate. Mater. Res., 14 [2], 248-255. http://dx.doi.org/10.1590/ S1516-14392011005000039.

127. Salem, R.M.; Burdette, E.G.; Jackson, N.M. (2003) Resistance to freezing and thawing of recycled aggregate concrete. ACI Mater. J., 100 [3], 216-221.

128. Saravana Kumar, P; Dhinakaran, G. (2012) Effect of admixed recycled aggregate concrete on properties of fresh and hardened concrete. J. Mater. Civ. Eng., 24 [4], 494498. http://dx.doi.org/10.1061/(ASCE)MT.1943-5533.0000393.

129. Sato, R.; Maruyama, I.; Sogabe, T.; Sogo, M. (2007) Flexural behavior of reinforced recycled concrete beams. J. Adv. Concr. Technol., 5 [1], 43-61. http://dx.doi.org/ $10.3151 /$ jact. 5.43

130. Seara-Paz, S.; González-Fonteboa, B.; Eiras-López, J.; Herrador, M.F. (2014) Bond behavior between steel reinforcement and recycled concrete. Mater. Struct., 47 [1-2], 323-334. http://dx.doi.org/10.1617/s11527-013-0063-z.

131. Seung-Tae, L. (2009) Influence of recycled fine aggregates on the resistance of mortars to magnesium sulfate attack. Waste Manage., 29 [8], 2385-2391. http://dx.doi. org/10.1016/j.wasman.2009.04.002.

132. Soares, D.; de Brito, J.; Ferreira, J.; Pacheco, J. (2014) Use of coarse recycled aggregates from precast concrete rejects: mechanical and durability performance. Constr. Build. Mater., 71, 263-272. http://dx.doi.org/10.1016/j.conbuildmat. 2014.08.034.

133. Somna, R; Jaturapitakkul, C. Chalee, W; Rattanachu, P. (2012) Effect of the water to binder ratio and ground fly ash on properties of recycled aggregate concrete. J. Mater. Civ. Eng., 24 [1], 16-22. http://dx.doi.org/10.1061/(ASCE) MT.1943-5533.0000360.

134. Sun, Y.; Xiang, X. (2011) Experiment research on basic mechanic property of recycled concrete with different ratio of recycled aggregate. Adv. Mater. Res., 250-253, 994-1000. http://dx.doi.org/10.4028/www.scientific.net/amr. 250-253.994.

135. Takayuki, F.; Masaru, Y. (2003) Strength and drying shrinkage of concrete used recycled aggregate. Mem. Fac. Eng., Osaka City Univ., 44, 79-82.

136. Tam, V.W.Y.; Gao, X.F.; Tam, C.M.; Ng, K.M. (2009) Physio-chemical reactions in recycle aggregate concrete. J. Hazard Mater., 163 [2-3], 823-828. http://dx.doi.org/ 10.1016/j.jhazmat.2008.07.031.

137. Tam, V.W.Y.; Le, K.N. (2007) Optimal aggregate testing using vandermonde polynomials and spectral methods. J. Hazard Mater., 145 [1-2], 72-99. http://dx.doi.org/ 10.1016/j.jhazmat.2006.10.094.

138. Tangchirapat, W.; Buranasing, R.; Jaturapitakkul, C. (2010) Use of high fineness of fly ash to improve properties of recycled aggregate concrete. J. Mater. Civ. Eng., 22 [6], 565-571. http://dx.doi.org/10.1061/(ASCE)MT.1943-5533. 0000054.

139. Thomas, C.; Sosa, I.; Setién, J.; Polanco, J.A.; Cimentada, A.I. (2014) Evaluation of the fatigue behavior of recycled aggregate concrete. J. Clean. Prod., 65, 397-405. http:// dx.doi.org/10.1016/j.jclepro.2013.09.036.
140. Thomas, C.; Setién, J.; Polanco, J. A.; Alaejos, P.; Sánchez de Juan, M. (2013) Durability of recycled aggregate concrete. Constr. Build. Mater., 40, 1054-1065. http://dx.doi. org/10.1016/j.conbuildmat.2012.11.106.

141. Tuyan, M.; Mardani-Aghabaglou, A.; Ramyar, K. (2014) Freeze-thaw resistance, mechanical and transport properties of self-consolidating concrete incorporating coarse recycled concrete aggregate. Mater. Design, 53, 983-991. http://dx.doi.org/10.1016/j.matdes.2013.07.100.

142. Vieira, J.P.B.; Correia, J.R.; De Brito, J. (2011) Post-fire residual mechanical properties of concrete made with recycled concrete coarse aggregates. Cem. Concr. Res., 41 [5], 533-541. http://dx.doi.org/10.1016/j.cemconres.2011.02.002.

143. Villagrán-Zaccardi, Y.A.; Zega, C.J.; Di Maio, Á.A. (2008) Chloride penetration and binding in recycled concrete. J. Mater. Civ. Eng., 20 [6], 449-455. http://dx.doi.org/ 10.1061/(ASCE)0899-1561(2008)20:6(449).

144. Wang, W.; Kou, S.; Xing, F. (2013) Deformation properties and direct shear of medium strength concrete prepared with 100\% recycled coarse aggregates. Constr. Build. Mater., 48, 187-193. http://dx.doi.org/10.1016/j.conbuildmat. 2013.06.065.

145. Won, L.; Sang, J.; Hyun, D. (2008) Shear strength of reinforced concrete beams with recycled aggregates. In Tailor Made Concrete Structures 225-225 CRC Press.

146. Xiao, J; Huang, X.; Shen, L. (2012) Seismic behavior of semi-precast column with recycled aggregate concrete. Constr. Build. Mater., 35, 988-1001. http://dx.doi. org/10.1016/j.conbuildmat.2012.04.062.

147. Xiao, J.; Xie, H.; Yang, Z. (2012) Shear transfer across a crack in recycled aggregate concrete. Cem. Concr. Res., 42 [5], 700-709. http://dx.doi.org/10.1016/j.cemconres.2012.02.006.

148. Xuping, L. (2009) Recycling and reuse of waste concrete in china: Part II. Structural behaviour of recycled aggregate concrete and engineering applications. Resour. Conserv. Recycl., 53 [3], 107-112. http://dx.doi.org/10.1016/j.resconrec. 2008.11 .005

149. Yildirim, S.T.; Meyer, C.; Herfellner, S. (2015) Effects of internal curing on the strength, drying shrinkage and freeze-thaw resistance of concrete containing recycled concrete aggregates. Constr. Build. Mater., 91, 288-296. http:// dx.doi.org/10.1016/j.conbuildmat.2015.05.045.

150. Younis, K.H.; Pilakoutas, K. (2013) Strength prediction model and methods for improving recycled aggregate concrete. Constr. Build. Mater., 49, 688-701. http://dx.doi.org/ 10.1016/j.conbuildmat.2013.09.003.

151. Zaharieva, R.; Buyle-Bodin, F.; Skoczylas, F.; Wirquin, E. (2003) Assessment of the surface permeation properties of recycled aggregate concrete. Cem. Concr. Compos., 25 [2], 223-232. http://dx.doi.org/10.1016/S0958-9465(02)00010-0.

152. Zega, C.J.; Di Maio, A.A. (2011) Use of recycled fine aggregate in concretes with durable requirements. Waste Manage., 31 [11], 2336-2340. http://dx.doi.org/10.1016/j. wasman.2011.06.011.

153. Zhang, W.; Ingham, J.M. (2010) Using recycled concrete aggregates in New Zealand ready-mix concrete production. J. Mater. Civ. Eng., 22 [5], 443-450. http://dx.doi. org/10.1061/(ASCE)MT.1943-5533.0000044.

154. Zhao, X.; Duan, M. (2013) Experimental research on mechanical properties of recycled aggregate concrete under uniaxial loading. Adv. Mater. Res., 671-674, 1736-1740. http://dx.doi.org/10.4028/www.scientific.net/AMR. 671-674.1736.

155. Silva, R.V.; De Brito, J.; Dhir, R.K. (2014) Properties and composition of recycled aggregates from construction and demolition waste suitable for concrete production. Constr. Build. Mater., 65, 201-217. http://dx.doi.org/10.1016/j. conbuildmat.2014.04.117.

156. Silva, R.V.; De Brito, J.; Dhir, R.K. (2015) The influence of the use of recycled aggregates on the compressive strength of concrete: A review. European J. Environ. Civ. Eng., 19 [7], 825-849. http://dx.doi.org/10.1080/19648189.2014.974831.

157. Duan, Z.H.; Kou, S.C.; Poon, C.S. (2013) Prediction of compressive strength of recycled aggregate concrete using artificial neural networks. Constr. Build. Mater., 40, 1200-1206. http://dx.doi.org/10.1016/j.conbuildmat.2012.04.063. 
158. Kim, S.; Choi, H.; Shin, Y.; Kim, G.; Seo, D. (2013) Optimizing the mixing proportion with neural networks based on genetic algorithms for recycled aggregate concrete. Adv. Mater. Sci. Eng. 2013. http://dx.doi.org/10.1155/ 2013/527089.

159. Alaejos, P.; Sánchez, M.; Vázquez, E.; et al. (2006) Use of Recycled Aggregate in the Production of Structural Concrete (in Spanish). Commission 2, Working Group 2/5 Recycled concrete, Monograph M-11 ACHE, Madrid.

160. Sánchez-Roldán, Z.; Martín-Morales, M.; ValverdePalacios, I.; Valverde-Espinosa, I.; Zamorano, M. (2016) Study of potential advantages of pre-soaking on the properties of pre-cast concrete made with recycled coarse aggregate. Mater. Construcc., 66 [321], e076. http://dx.doi. org/10.3989/mc.2016.01715.

161. Fernández-Ledesma, E.; Jiménez, J.R:; Ayuso, J. Corinaldesi, V.; Iglesias-Godino, F.J. (2016) A proposal for the maximum use of recycled concrete sand in masonry mortar design. Mater. Construcc., 66 [321], e075. http:// dx.doi.org/10.3989/mc.2016.08414.

162. Gonçalves, P.; De Brito, J. (2010) Recycled aggregate concrete (RAC) - comparative analysis of existing specifications. Mag. Concr. Res., 62 [5], 339-346. http://dx.doi. org/10.1680/macr.2008.62.5.339.

163. BSI (British Standards Institution) (2002) BS 8500-2: Concrete - complementary British standard to BS EN 206-1. Part 2: Specification for constituent materials and concrete. BSI, London.

164. DIN (Deutsches Institut für Normung) (2002) DIN 4226100: 2002-2: Aggregates for mortar and concrete. Part 100: recycled aggregates. DIN, Berlin.

165. LNEC (National Laboratory of Civil Engineering) (2006) LNEC E 471. Guideline for the Use of Recycled Coarse Aggregates in Hydraulic Binders' Concrete. National Laboratory of Civil Engineering. Portugal (in Portuguese).

166. Ot (Objectif technique) (2006) 70085 Instruction technique. Utilisation de matériaux de construction minéraux secondaires dans la construction d'abris (in French). Ot, Switzerland, 2006.

167. RILEM (1994) TC 121-DRG Specifications for concrete with recycled aggregates. Materials and Structures, 27 [173], 557-559.

168. WBTC (2002) WBTC No. 12/2002: Specifications Facilitating the Use of Recycled Aggregates. Works Bureau Technical Circular, Hong-Kong.

169. EHE-08 - Spanish Instruction for Structural Concrete (2008) Ministry of Public Works, August-08 (in Spanish).

170. Jiménez, C.; Barra, M.; Valls, S.; Aponte, D.; Vázquez, E. (2014) Durability of recycled aggregate concrete designed with the Equivalent Mortar Volume (EMV) method: Validation under the Spanish context and its adaptation to Bolomey methodology. Mater. Construcc., 64 [313], e006. http://dx.doi.org/10.3989/mc.2014.00913.

171. De Juan, M.S.; Gutiérrez, P.A. (2009) Study on the influence of attached mortar content on the properties of recycled concrete aggregate. Constr. Build. Mater., 23 [2], 872-877. http://dx.doi.org/10.1016/j.conbuildmat.2008.04.012.

172. Tam, V.W.Y.; Tam, C.M.; Le, K.N. (2007) Removal of cement mortar remains from recycled aggregate using presoaking approaches. Resour. Conserv. Recycl., 50 [1], 82-101. http://dx.doi.org/10.1016/j.resconrec.2006.05.012.

173. Spaeth, V.; Djerbi Tegguer, A. (2013) Improvement of recycled concrete aggregate properties by polymer treatments. Int. J. Sustain. Built Environ., 2, 143-152. http://dx.doi.org/ 10.1016/j.ijsbe.2014.03.003.

174. Seo, D.S.; Choi, H.B. (2014) Effects of the old cement mortar attached to the recycled aggregate surface on the bond characteristics between aggregate and cement mortar. Constr. Build. Mater., 59, 72-77. http://dx.doi. org/10.1016/j.conbuildmat.2014.02.047.

175. Xuping, L. (2008) Recycling and reuse of waste concrete in china: Part I. Material behaviour of recycled aggregate concrete. Resour. Conserv. Recycl., 53, 36-44. http://dx.doi. org/10.1016/j.resconrec.2008.09.006.

176. Martín-Morales, M.; Zamorano, M.; Ruiz-Moyano, A.; Valverde-Espinosa, I. (2011) Characterization of recycled aggregates construction and demolition waste for concrete production following the Spanish structural concrete code EHE-08. Constr. Build. Mater., 25 [2], 742-748. http:// dx.doi.org/10.1016/j.conbuildmat.2010.07.012.

177. González-Fonteboa, B.; Martínez-Abella, F. (2008) Concretes with aggregates from demolition waste and silica fume. materials and mechanical properties. Build. Environ., 43 [4], 429-437. http://dx.doi.org/10.1016/j.buildenv.2007. 01.008 .

178. González, B. (2002) Hormigones con áridos reciclados procedentes de demoliciones: dosificación, propiedades mecánicas y comportamiento estructural a cortante. $\mathrm{PhD}$ Dissertation, University of A Coruña, Spain.

179. Saiz-Martínez, P.; González-Cortina, M.; FernándezMartínez, F. (2015) Characterization and influence of fine recycled aggregates on masonry mortars properties. Mater. Construcc., 65 [319], e058. http://dx.doi.org/10.3989/mc. 2015.06014

180. López, F. (2008) Influencia de la variación de los parámetros de dosificación y fabricación de hormigón reciclado estructural sobre sus propiedades físicas y mecánicas. PhD Dissertation, University of Oviedo, Spain

181. Japanese Standards Association (2005) (JIS A 5021). Recycled Aggregate for Concrete-class H. Japanese Standards Association, Tokyo.

182. Japanese Standards Association (2006) (JIS A 5022). Recycled Aggregate for Concrete-class M. Japanese Standards Association, Tokyo.

183. Japanese Standards Association (2007) (JIS A 5023). Recycled Aggregate for Concrete-class L. Japanese Standards Association, Tokyo.

184. NBR (Associação Brasileira de Normas Técnicas) (2005) NBR 15.116: Recycled aggregates from construction and demolition waste: non-structural concrete - requirements (in Portuguese). Associação Brasileira de Normas Técnicas, Rio de Janeiro.

185. Rühl, M. (1992) Water Absorption Capacity of Recycled Demolition Rubbish.

186. Tam, V.W.Y.; Wang, K.; Tam, C.M. (2008) Assessing relationships among properties of demolished concrete, recycled aggregate and recycled aggregate concrete using regression analysis. J. Hazard Mater., 152, 703-714. http:// dx.doi.org/10.1016/j.jhazmat.2007.07.061.

187. Zega, C.J.; Villagrán-Zaccardi, Y.A.; Di Maio, A.A. (2010) Effect of natural coarse aggregate type on the physical and mechanical properties of recycled coarse aggregates. Mater. Struct., 43, 195-202. http://dx.doi.org/10.1617/ s11527-009-9480-4.

188. Haitao, Y.; Shizhu, T. (2015) Preparation and properties of high-strength recycled concrete in cold areas. Mater. Construcc., 65 [318], e050. http://dx.doi.org/10.3989/mc. 2015.03214

189. Etxeberria, M.; Vázquez, E.; Marí, A. (2006) Microstructure analysis of hardened recycled aggregate concrete. Mag. Concr. Res., 58 [10], 683-690. http://dx.doi.org/10.1680/macr. 2006.58 .10 .683

190. González-Fonteboa, B.; Martínez-Abella, F.; Eiras-López, J.; Seara-Paz, S. (2011) Effect of recycled coarse aggregate on damage of recycled concrete. Mater. Struct., 1-13. http:// dx.doi.org/10.1617/s11527-011-9736-7. 